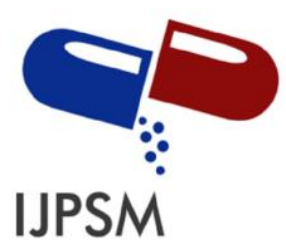

Isirima, Joshua Charles et al, Int. Journal of Pharmaceutical Sciences and Medicine (IJPSM),

Vol.6 Issue. 1, January- 2021, pg. 8-30

ISSN: 2519-9889

Impact Factor: 3.426

\title{
Evidence of Hepato-Curative Potentials of Millettia aboensis in Salmonella typhi infected Wistar Rats
}

\author{
Isirima, Joshua Charles ${ }^{1}$ and Angalabiri-Owei, Bekekeme Etoro ${ }^{2}$ \\ ${ }^{1}$ Department of Biomedical Technology, School of Science Laboratory Technology, University of Port Harcourt, Nigeria \\ ${ }^{2}$ Department of Pharmacology, Faculty of Basic Medical Sciences, College of Health Sciences, Niger Delta University, Bayelsa State, Nigeria
}

Corresponding Author: Isirima, Joshua Charles

Email: joshuasrm964@gmail.com

Phone Numbers: 08076080566, 08182200149

DOI: 10.47760/ijpsm.2021.v06i01.002

\begin{abstract}
Typhoid fever is a systemic infection caused by the bacterium Salmonella enterica subspecies enterica serotype typhi, a foremost public health predicament in developing countries. This study investigated hepatotoxicological changes associated with Salmonella typhi infection in Wistar rats and the potential of ethanol root extract of Millettia aboensis (EREMA) to reverse these changes. 51 animals were divided into six groups: group 1 was normal control with no treatment but were given feed and water ad libitum, group 2 was infected with Salmonella typhi without treatment (negative control), group 3, 4 and 5 were Salmonella typhi infected and treated with $100 \mathrm{mg} / \mathrm{kg}, 200 \mathrm{mg} / \mathrm{kg}$ and $400 \mathrm{mg} / \mathrm{kg}$ of the extract respectively, and group 6 was infected and treated with $7.14 \mathrm{mg} / \mathrm{kg}$ of ciprofloxacin. The animals were inoculated with a single infectious dose of Salmonella typhi bacterium $\left(2.0 \times 10^{8} \mathrm{cfu} / \mathrm{ml}\right)$ and were subsequently treated with the graded doses of the extract and $7.14 \mathrm{mg} / \mathrm{kg}$ of ciprofloxacin for a period of fifteen days. The rats were humanely sacrificed using diethyl ether anesthesia and blood samples taken for liver function investigation including [aspartate aminotransferase (AST) alanine aminotransferase (ALT), alkaline phosphatase (ALP), total bilirubin (TB), Albumin, conjugate bilirubin (CB) and total protein (TP)] and liver harvested and processed for histological assessment. Inoculation with $S$. typhi caused significant increase in all the liver function parameters and different degrees of damages to the liver cells. These were all reversed on treatment with ethanol root extract of Millettia aboensis. Thus the extract exhibited both anti-Salmonella typhi as well as hepato-curative potentials on the Kuffer cells. Keywords: Chromolaena odorata, Hepato-curative, Salmonella typhi, Wistar Rats
\end{abstract}

\section{Introduction}

Typhoid fever is a systemic infection caused by the bacterium Salmonella enterica subspecies enterica serotype typhi (Iroha et al., 2010). It constitutes a foremost public health predicament in many developing nations of the world (Crump, et al., 2004). Typhoid fever principally attacks children and young adults and is known to be a major cause of global morbidity with over 600,000 deaths annually (Abro et al., 2009 and Wasfy et al., 2000). Salmonella typhi is transmitted via the faecal-oral route, both directly from person to person or by ingestion of food or water contaminated with faeces (Ivanoff, 1995). The characteristics of the disease in its early stage include high fever, anorexia, colic pain, malaise, lethargy, diarrhea and dull continuous headache. During advanced stages of the disease, it is indicated by mental dullness and protracted fever, while other symptoms may include slight deafness, intestinal bleeding, and parotitis paratyphoid (Ackers, 2000). Typhoid fever usually is connected with hepatic pathology, even though, Abro et al., (2009) showed that rigorous liver injury causing delicate viral hepatitis is rare. Although, hepatitis patho-genesis is unclear, liver cells destruction in 


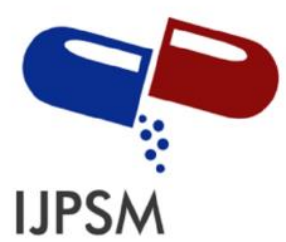

Isirima, Joshua Charles et al, Int. Journal of Pharmaceutical Sciences and Medicine (IJPSM), Vol.6 Issue. 1, January- 2021, pg. 8-30

ISSN: 2519-9889

Impact Factor: 3.426

typhoid related illness has various mechanisms involving regional or general adverse activities of specific endotoxin, unspecified inflammatory response to gastro-intestinal injury together with cyto-toxins produced and discharged by S. typhi in Kupffer cells (Abro et al., 2009). The regular occurrence of hepatic enzyme in typhoid fever was shown to be (22\%, 26\% and 52\%) in different situations (Morgenstern \& Hayes, 1991 and Mirsadraee et al., 2007), while Ozen in 1995, reported that typhoid fever disease is associated with abnormal liver function tests in about 50\% of patients, similarly, Abro et al., (2009) also described a more regular occurrence for alanine transaminase in typhoid patients in proportions of (73.3\%). In a research to treat $S$. typhi infection in rats using Momordica charatia, Adeyi, et al., (2013), found that infection with S. typhi resulted in a rise in the levels of Gamma-glutamyl-transferase, ALP, AST, ALT and TB. Also in a similar study by Isirima and Siminialayi (2018), to treat S. typhi infection in Wistar rats with Chromolaea odorata, it was reported that inoculation of Wistar rats with Salmonella typhi caused an increase in the levels of aspartate aminotransferase (AST), alanine aminotransferase (ALT), alkaline phosphatase (ALP), total bilirubin (TB), albumin and total protein (TP), and an insignificant increase in Conjugated Billirubin (CB) as well as hepatic necrosis on histological examination. The World Health Organization (WHO) reported that more than $80 \%$ of the world's population depends on traditional medicine for their principal healthcare needs, and a larger proportion of this comes from plants sources or their active principles (Gupta et al., 2005). Plants used in traditional medical practice contain an extensive variety of ingredients that can be used to treat both infectious and chronic diseases (Iroha et al., 2010). According to (Sarkiyay et al., 2011), microbial infections poses severe health crisis in the entire globe and that plants are possible source of antimicrobial agents. (Sarkiyay et al., 2011) equally reported that medicinal plants contain active principles which could serve as substitute for inexpensive and valuable herbal drugs against frequent bacterial infections. Millettia aboensis occur in the family of Fabaceae. It is frequently called 'Uturuekpa' in South Eastern part of Nigeria. The plant is a small tree of about 30-40 feet tall, and up to 2 feet in thickness, usually dressed with reddish-brown pubescence on the inflorescence, branches, fruits and petioles (Adonu et al., 2013). The plant is usually found in low land rain forest, with evidently beautiful purple flowers in erect terminal racemes at branches and rusty-hairy leaves (Uba 2010). The aqueous and ethanol extracts of the plant have been reported to possess hepatoprotective potentials against Paracetamol induced hepatotoxicity, reversing liver enzymes (AST, ALT, ALP and serum total and conjugated Bilirubin) near to normal levels in a concentration dependent manner (Attama et al., 2014).

\section{Methods \\ Plant Collection}

The plant was harvested from natural habitat in Ika community, Akwa-Ibom State, Nigeria in the month of September and Plant roots was identified and authenticated at herbarium unit, in the department of plant science and biotechnology, Faculty of Sciences, University of Port Harcourt, River State, Nigeria with herbarium number UPH/P/104 by Mr. Ekeke Chimezie (Ph.D.)

\section{Isolation of Test Organisms}

The test organism, $S$ typhi was isolated from patients with typhoid fever in University of Port Harcourt Teaching Hospital (UPTH), Rivers State. The enrichment media used in course of the isolation of the organism include; strep-tokinase broth (Watson, 1978) and Bile salt broth (Watson, 1954). The samples presenting perceptible turbidity were sub-cultured on the medium "Mac-Conkey agar". Subsequently, traditional biochemical tests and PCR were used to identify the isolates exhibiting specific colonies

\section{Extraction Method}

The bark of the root of the plant were shredded out using cutlass, washed with clean tap water and allowed to dry at room temperature between $32-35^{\circ} \mathrm{C}$, until they attained a constant weight. The extraction method used was adapted from Hanan et al., (2013) cold maceration extraction protocol, with diminutive adjustment. The powdered $M$ aboensis root bark of about $50 \mathrm{~g}$ was soaked in $70 \%$ ethanol of about $1000 \mathrm{ml}$ in a 2 litre flask and mixed forcefully at $1 \mathrm{hr}$ intermission, for $12 \mathrm{hrs}$ and allowed to settle over-night $\left(35^{\circ} \mathrm{C}\right)$ to allow for adequate extraction. Subsequently, the concoction was filtered by means of a filter paper with pore size of 0.45 milli-pore. 


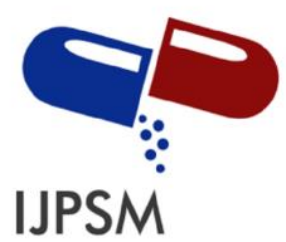

Isirima, Joshua Charles et al, Int. Journal of Pharmaceutical Sciences and Medicine (IJPSM), Vol.6 Issue. 1, January- 2021, pg. 8-30

ISSN: 2519-9889

Impact Factor: 3.426

The concentration of the extract was increase using rotary evaporation process at $40^{\circ} \mathrm{C}$ and $200 \mathrm{rpm}$. The final semi-solid extract was obtained by drying the content of the rotary evaporator over a steam bath at $40^{\circ} \mathrm{C}$. The resultant extract obtained $20 \%$ yield, was kept safe at room temperature in desiccators, until it was needed for the study.

\section{Experimental Design}

Fifty one (51) animals were separated into 6 groups. Group 1 (normal) had three (3) animals, Group 2 (negative control) had twelve (12) animals, while groups 3-6 each had nine (9) animals. Group 1 animals were not treated throughout the experimental period but were given free access to normal animal feed and water ad labitum. Group 2 contained Salmonella typhi-infected rats not treated after disease induction. Group 3 contained Salmonella typhi-infected rats treated with $100 \mathrm{mg} / \mathrm{kg}$ (low dose) of Milletia aboensis root extract. Group 4 contained Salmonella typhi-infected rats treated with $200 \mathrm{mg} / \mathrm{kg}$ (medium dose) of ethanol root extract of Milletia aboensis. Group 5 contained Salmonella typhi-infected rats treated with $400 \mathrm{mg} / \mathrm{kg}$ (high dose) of ethanol root extract of Milletia aboensis. Group 6 contained Salmonella typhi-infected rats treated with $500 \mathrm{mg} / 70 \mathrm{~kg}(7.14 \mathrm{mg} / \mathrm{kg}$ ) of a standard antibiotic drug (Ciprofloxacin). On day 0 , (when the animals were confirmed infected, through observation of anorexia, weakness and diarrhea from the animals as well as isolation of the organism from the animal stool), and at six day intervals and on day sixteen, 3 animals from each group were humanely sacrificed and blood was collected and the liver removed for assessment of the liver function parameters and histopathological examination, respectively.

\section{Challenging apparently healthy animals with Salmonella typhi}

Forty eight (48) animals (groups 2-6) were orogastrically challenged with an infective dose $\left(2.0 \times 10^{8} \mathrm{cfu} / \mathrm{ml}\right)$ of Salmonella typhi. After infection had set in (through observation of signs like weakness, anorexia, nonproductive cough, watery stool, standing of the hairs as in cold condition and isolation of the organism from the animal stool) (day 0), three animals were sacrificed and blood samples and liver tissues collected for preliminary screening while the other 45 animals were treated with the ethanol extract of Milletia aboensis according to the different doses and the standard antibiotic (Ciprofloxacin), once daily, for fifteen days.

\section{Preparation of the Extract Concentrations and Antibiotic}

Stock solution for the extract was prepared by dissolving $500 \mathrm{mg}$ in $1 \mathrm{ml}$ of sterile distilled water. An antibiotic control was made by dissolving 500mg of ciprofloxacin in sterile distilled water.

\section{Blood collection and dissection}

Blood was collected from each animal by cardiac puncture method after the animals were anaesthetized with diethyl ether in a desiccator. The blood was immediately transferred into appropriately labelled sample bottles containing anticoagulant and the liver was removed aseptically and was weighed and a portion was kept for histological analysis.

\section{Liver Function Test Analysis}

Aspartate aminotransferase (AST) and alanine aminotransferase (ALT) determinations were carried out using Randox automated method and the methods of Reitman \& Frankel (1957) and Schmidt, \& Schmidt, (1963), while alkaline phosphatase (ALP) determination was carried out using Randox automated method and the methods of Klein, \& Babson, (1960) and Babson, et al., (1966). In a similar manner total protein (TP) determination was carried out using Randox automated method and the method of Tietz (1995), while albumin (ALB) and bilirubin (BIL) determinations were carried out using Randox automated method and the methods of Grant (1987) and Doumas, et al., (1971). 


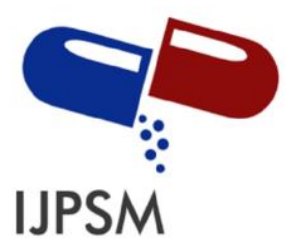

Isirima, Joshua Charles et al, Int. Journal of Pharmaceutical Sciences and Medicine (IJPSM), Vol.6 Issue. 1, January- 2021, pg. 8-30

ISSN: 2519-9889

Impact Factor: 3.426

\section{Histopathology Studies}

The animals were anaesthetized with diethyl ether, dissected aseptically to remove the liver which was then transferred into $10 \%$ chloroform and later trimmed down to a size between $2 \mathrm{~mm}$ to $4 \mathrm{~mm}$ thickness, to allow the fixative to readily penetrate the tissue. The tissues were exposed to different stages of processing by standard methods as described by Baker (1945), including, fixation, dehydration, clearing, impregnation, embedding, sectioning and staining with hematoxylin and eosin (H\&E) and finally mounting.

\section{Statistical Analysis}

The results are presented as Mean \pm Standard error of mean. Differences between means were assessed using Analysis of variance (ANOVA) and post test using LSD multiple comparison test (Mead, \& Curnow, 1982).

\section{Results}

\section{Effect of ethanol root extract of Milletia aboensis on liver function parameters in S. typhi infected Wistar rats}

Inoculation with only one infective dose of $S$. typhi to rats showed a significant elevation $(\mathrm{p}<0.05)$ in TP, TB, ALP, ALT, AST and albumin levels apart from CB which recorded an insignificant change when compared to normal control. On the contrary, treatment with ethanol root extract of Milletia aboensis (EREMA) and ciprofloxacin reversed the observed elevations, producing a stable reduction across the parameters on days $11^{\text {th }}$ and $16^{\text {th }}$ days as shown in figures $1,2,3,4,6$, and 7 , as well as a significant difference $(\mathrm{p}<0.05)$ between treatment groups and negative control on the $16^{\text {th }}$ day in $\mathrm{CB}$ as presented in figure 5.

\section{Effect of ethanol root extract of Milletia aboensis on liver histology in Salmonella typhi infected Wistar rats}

Histological assessment of hepatic tissues from un-treated rats demonstrated normal hepatocytes histoarchitecture but harsh necrosis was noted in untreated S. typhi infected rats. For rats infected and administered with $100 \mathrm{mg} / \mathrm{kg}$ of ethanol root extract of Milletia aboensis for 5 days, it was observed that there was a high level of inflammatory polymophornuclear cells, with the portal triad showing hepatic artery and vein as indicated by the arrow I plate 3; while animals treated with $200 \mathrm{mg} / \mathrm{kg}$ of extract for 5 days revealed, liver with a prominent central vein (as indicated by the arrow in plate 4), with readily placed hepatic plates and well dilated sinosoids. Rats treated with $400 \mathrm{mg} / \mathrm{kg}$ of extract for 5 days showed liver with central veins from the liver lobules in proper position indicating normal architectural appearance (plate 5). The histology of the liver in animals treated with $100 \mathrm{mg} / \mathrm{kg}$, for 10 days revealed poorly differentiated liver cells although with well dilated sinusoids and the presence of inflammatory cells (plate 9); while for $200 \mathrm{mg} / \mathrm{kg}$ for 10 days showed hepatic lobule containing hepatic plates that are radially placed with dilated sinusoids and marked interlobar region containing branches of hepatic arteries and portal vein without inflammatory cells (plate 10); and for those treated with $400 \mathrm{mg} / \mathrm{kg}$ for 10 days showed normal hepatocytes and central vein (plate 11). Also among the histological tissues of the liver cells treated with $100 \mathrm{mg} / \mathrm{kg}, 200 \mathrm{mg} / \mathrm{kg}$ and $400 \mathrm{mg} / \mathrm{kg}$, for 15 days only those with $400 \mathrm{mg} / \mathrm{kg}$ revealed normal hepatocytes. These are shown in plates 15,16 and 17 respectively. The hepatic histo-architecture following infection and a five days course of treatment with Ciprofloxacin $(500 \mathrm{mg} / 70 \mathrm{~kg})$, showed no disrupted tissues and portal triad as shown in plate 6 and normal sinusoids without inflammation as well as sinusoids with clear hepatic plates devoid of any inflammatory cells after 10 days therapy (plate 12), while animals treated for 15 days with Ciprofloxacin $(500 \mathrm{mg} / 70 \mathrm{~kg} / \mathrm{kg}$ ) showed inter-lobular section having crowded inter-lobular portal vein. 


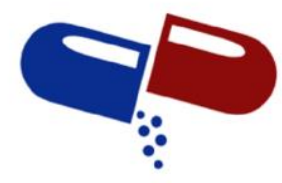

IJPSM

Isirima, Joshua Charles et al, Int. Journal of Pharmaceutical Sciences and Medicine (IJPSM), Vol.6 Issue. 1, January- 2021, pg. 8-30

ISSN: 2519-9889

Impact Factor: 3.426

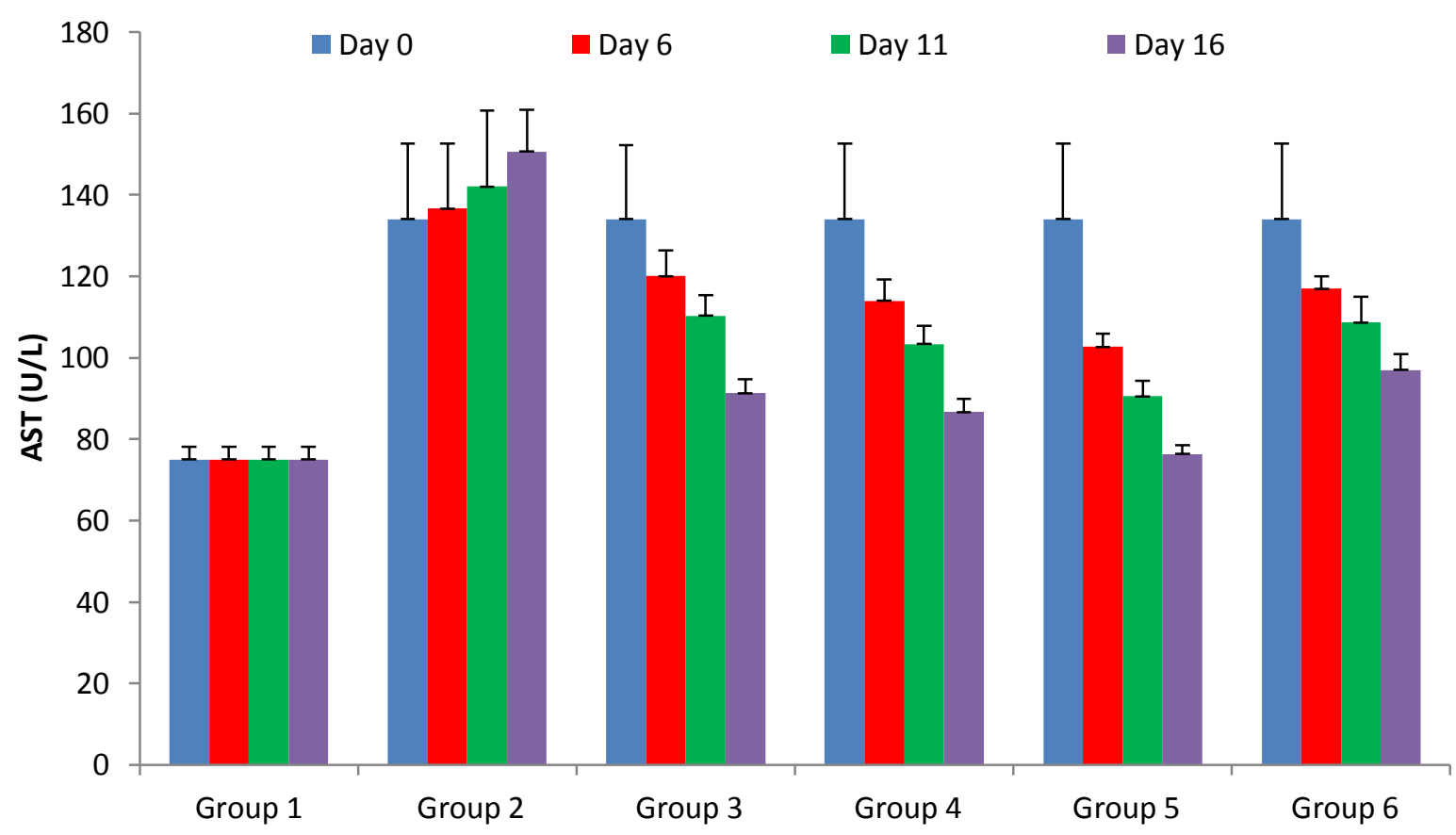

Figure 1: Aspartate aminotransferase (AST) of Albino Rats exposed to Salmonella typhi bacteria before treatment with Milletia aboensis 


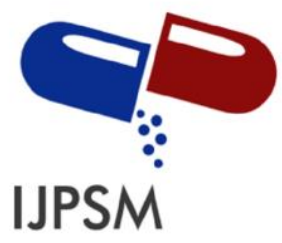

Isirima, Joshua Charles et al, Int. Journal of Pharmaceutical Sciences and Medicine (IJPSM), Vol.6 Issue. 1, January- 2021, pg. 8-30

ISSN: 2519-9889

Impact Factor: 3.426

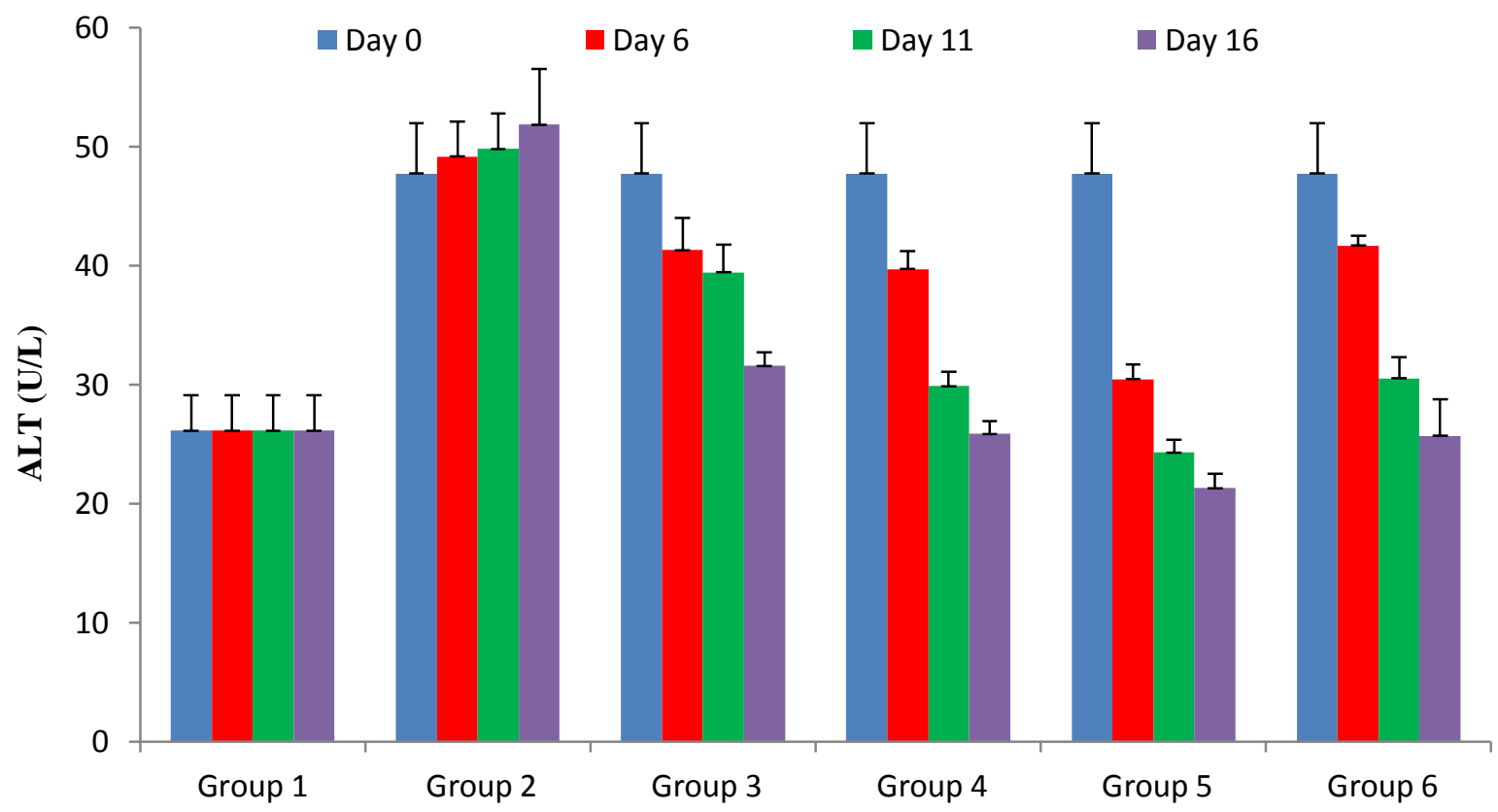

Figure 2: Alanine aminotransferase (ALT) of Albino Rats exposed to Salmonella typhi bacteria before treatment with Milletia aboensis 


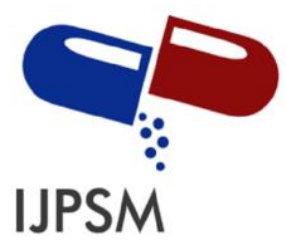

Isirima, Joshua Charles et al, Int. Journal of Pharmaceutical Sciences and Medicine (IJPSM), Vol.6 Issue. 1, January- 2021, pg. 8-30

ISSN: 2519-9889

Impact Factor: 3.426

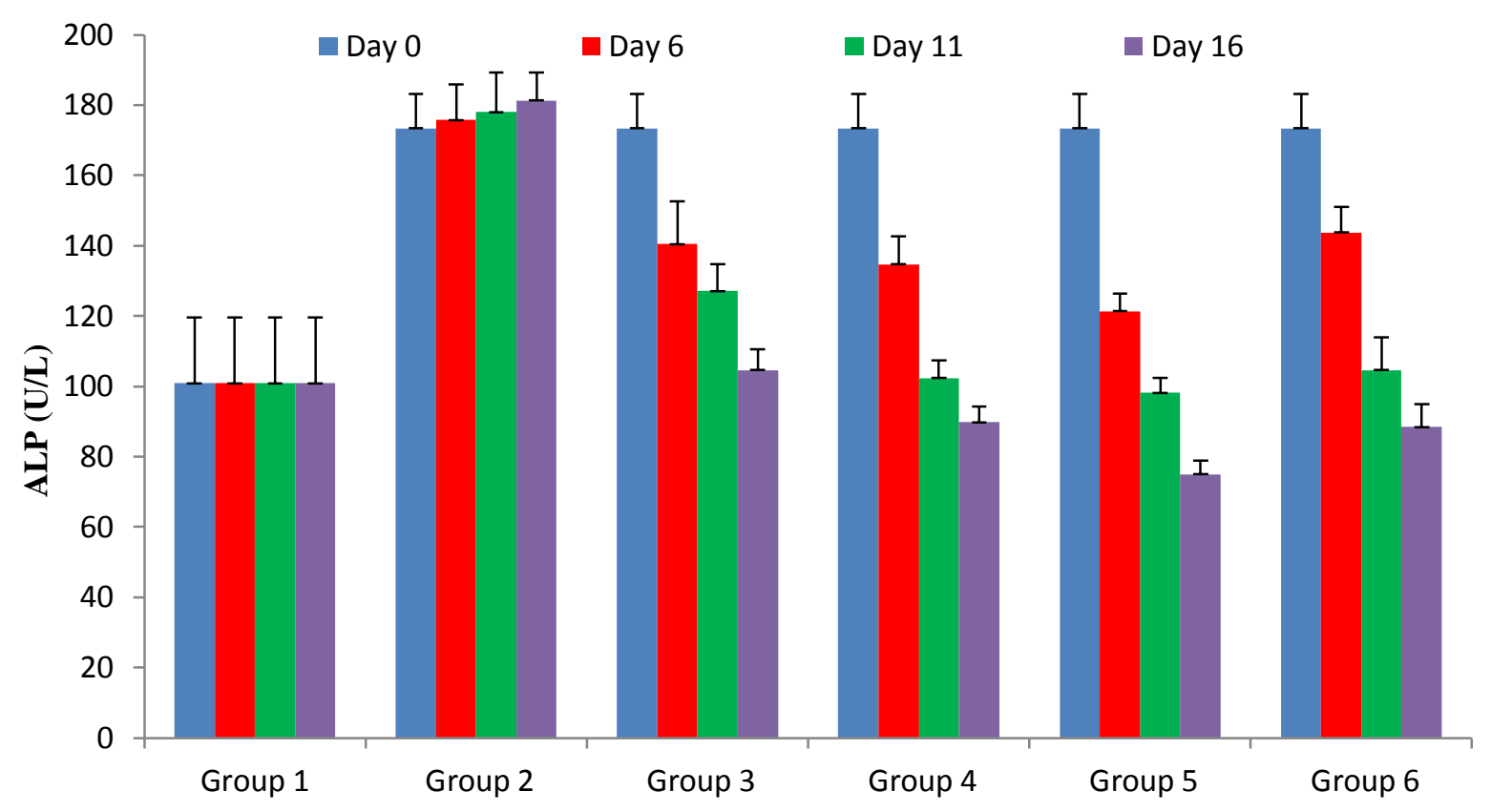

Figure 3: Alkaline Phosphatase (ALP) of Albino Rats exposed to Salmonella typhi bacteria before treatment with Milletia aboensis 


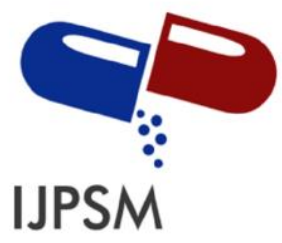

Isirima, Joshua Charles et al, Int. Journal of Pharmaceutical Sciences and Medicine (IJPSM), Vol.6 Issue. 1, January- 2021, pg. 8-30

ISSN: 2519-9889

Impact Factor: 3.426

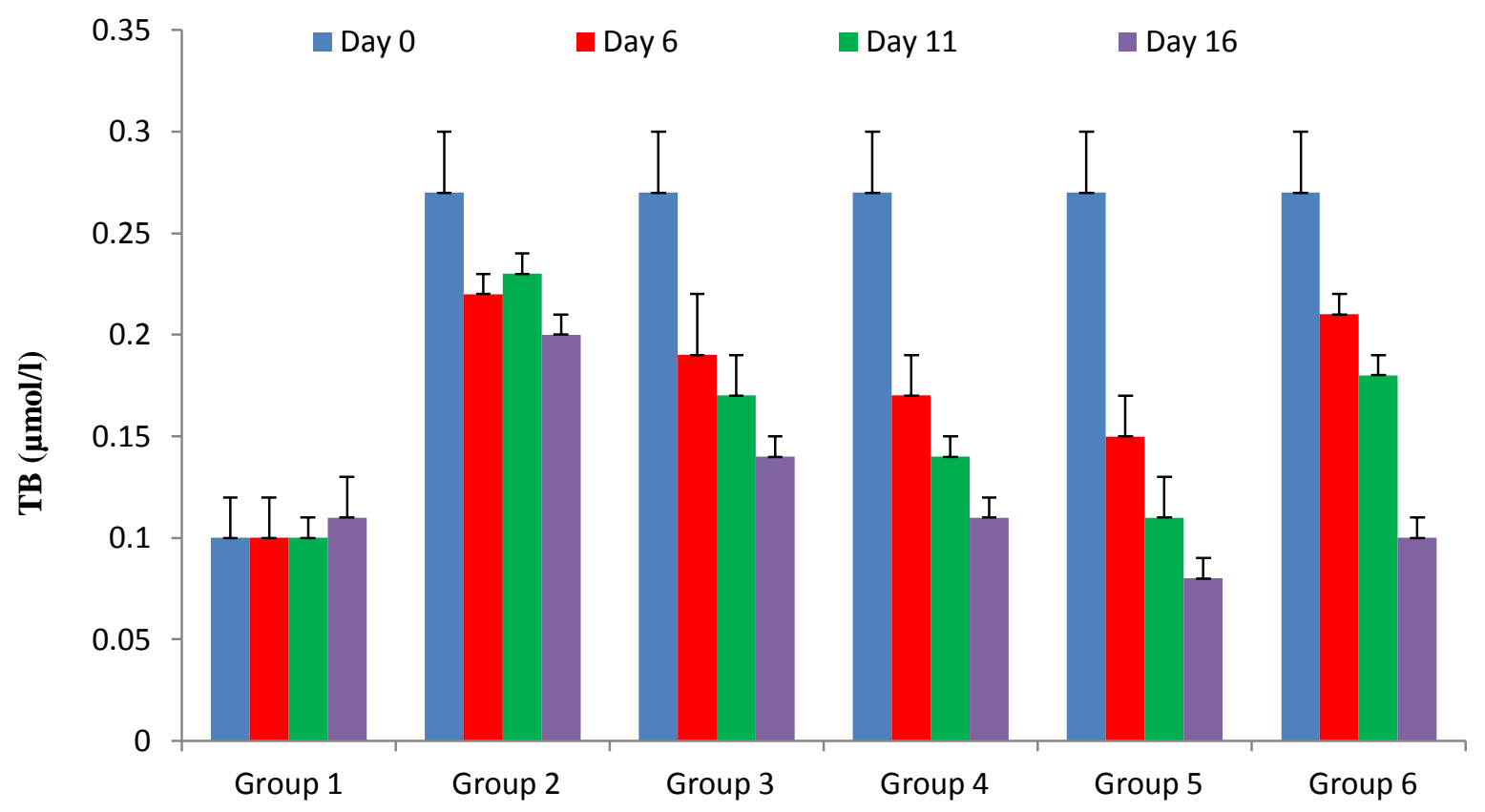

Figure 4: Total Bilirubin (TB) of Albino Rats exposed to Salmonella typhi bacteria before treatment with Milletia aboensis 


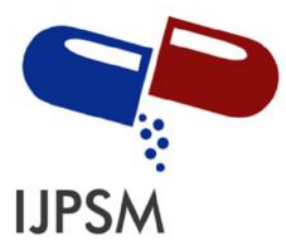

Isirima, Joshua Charles et al, Int. Journal of Pharmaceutical Sciences and Medicine (IJPSM), Vol.6 Issue. 1, January- 2021, pg. 8-30

ISSN: 2519-9889

Impact Factor: 3.426

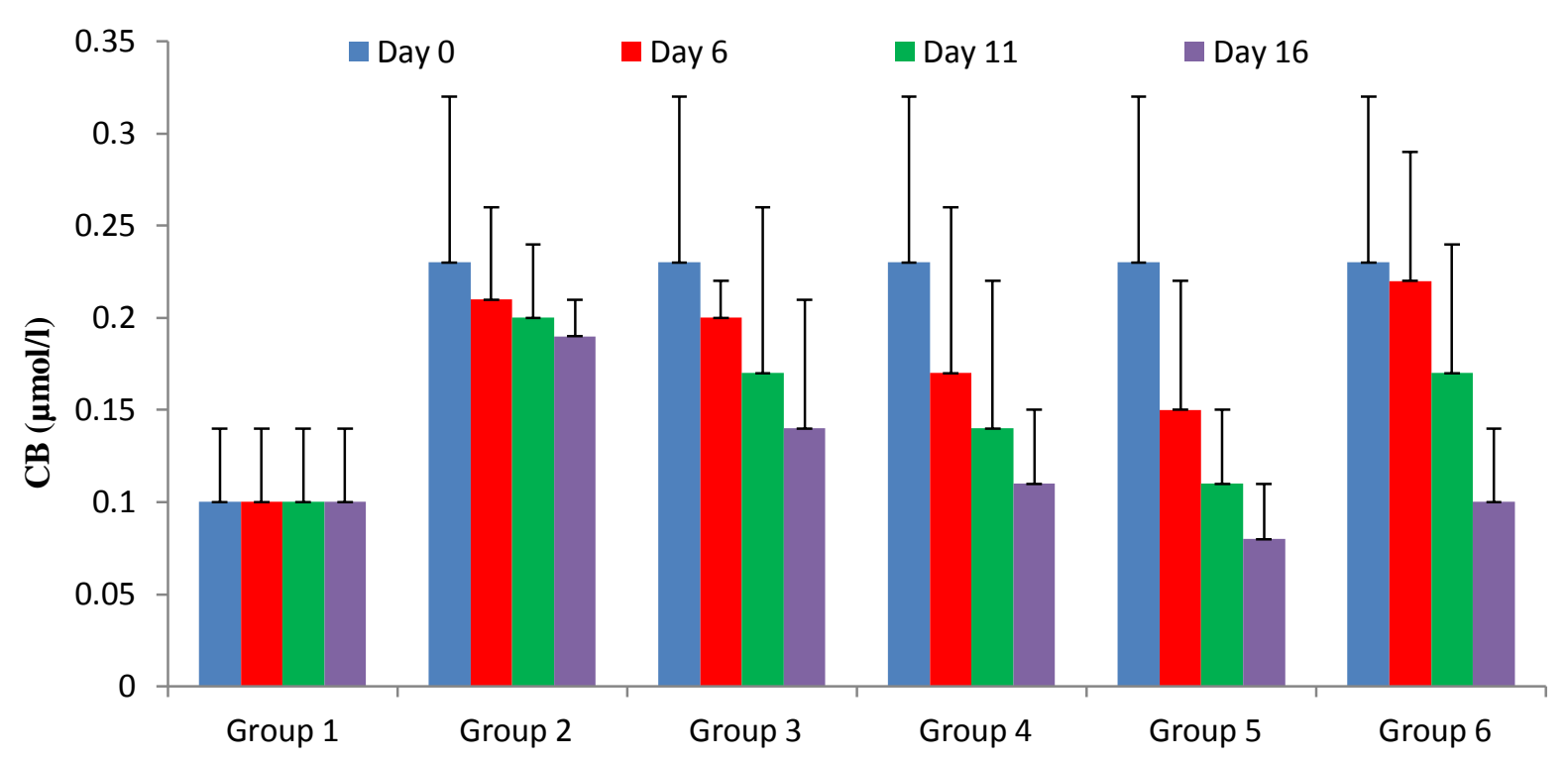

Figure 5: Conjugate Bilirubin (TB) of Albino Rats exposed to Salmonella typhi bacteria before treatment with Milletia aboensis 


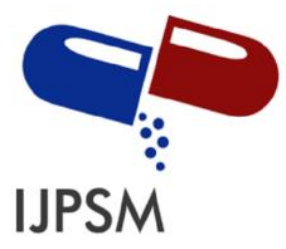

Isirima, Joshua Charles et al, Int. Journal of Pharmaceutical Sciences and Medicine (IJPSM), Vol.6 Issue. 1, January- 2021, pg. 8-30

ISSN: 2519-9889

Impact Factor: 3.426

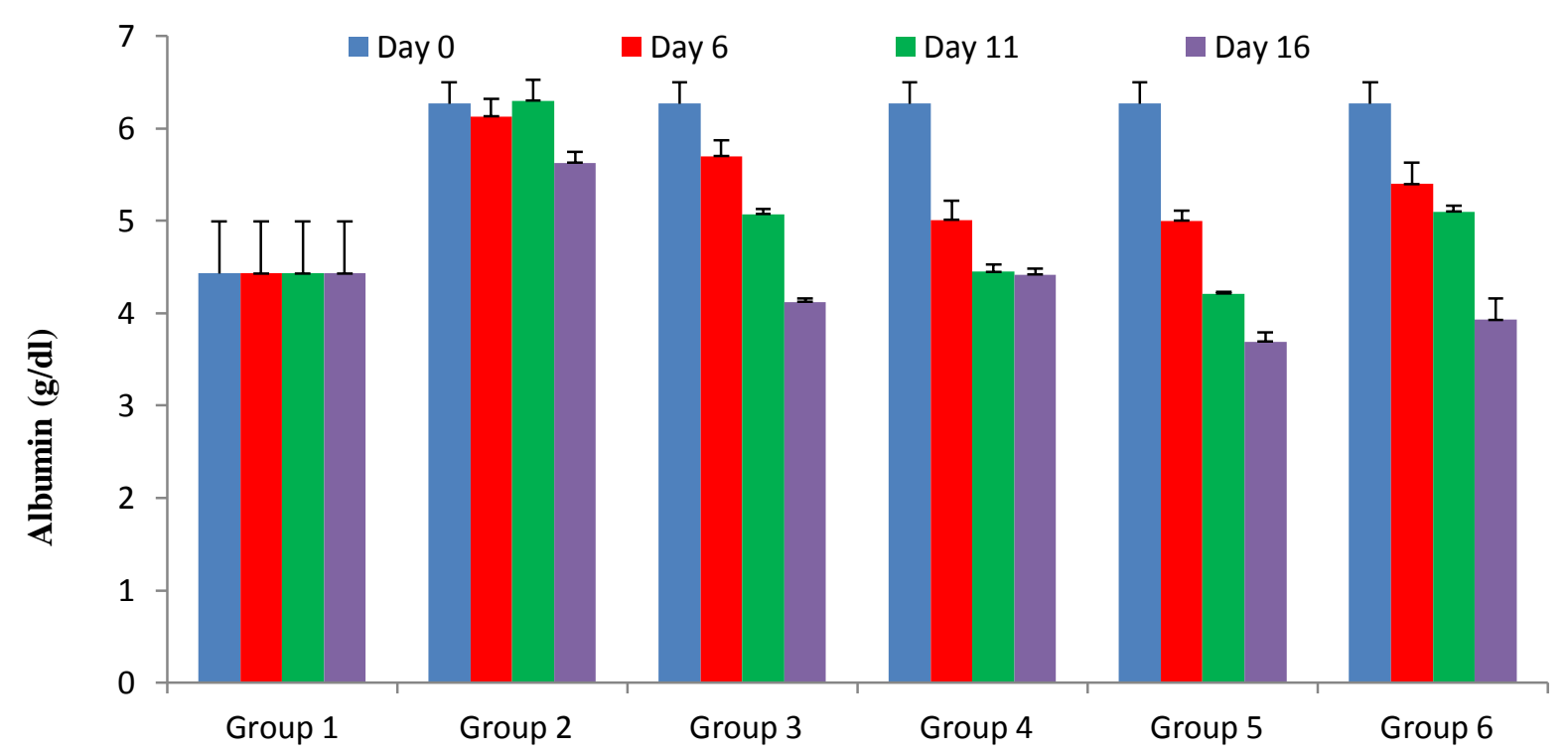

Figure 6: Albumin levels of Albino Rats exposed to Salmonella typhi bacteria before treatment with Milletia aboensis 


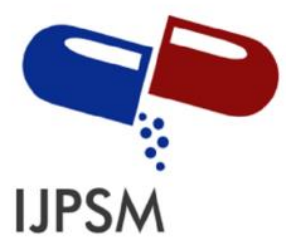

Isirima, Joshua Charles et al, Int. Journal of Pharmaceutical Sciences and Medicine (IJPSM), Vol.6 Issue. 1, January- 2021, pg. 8-30

ISSN: 2519-9889

Impact Factor: 3.426

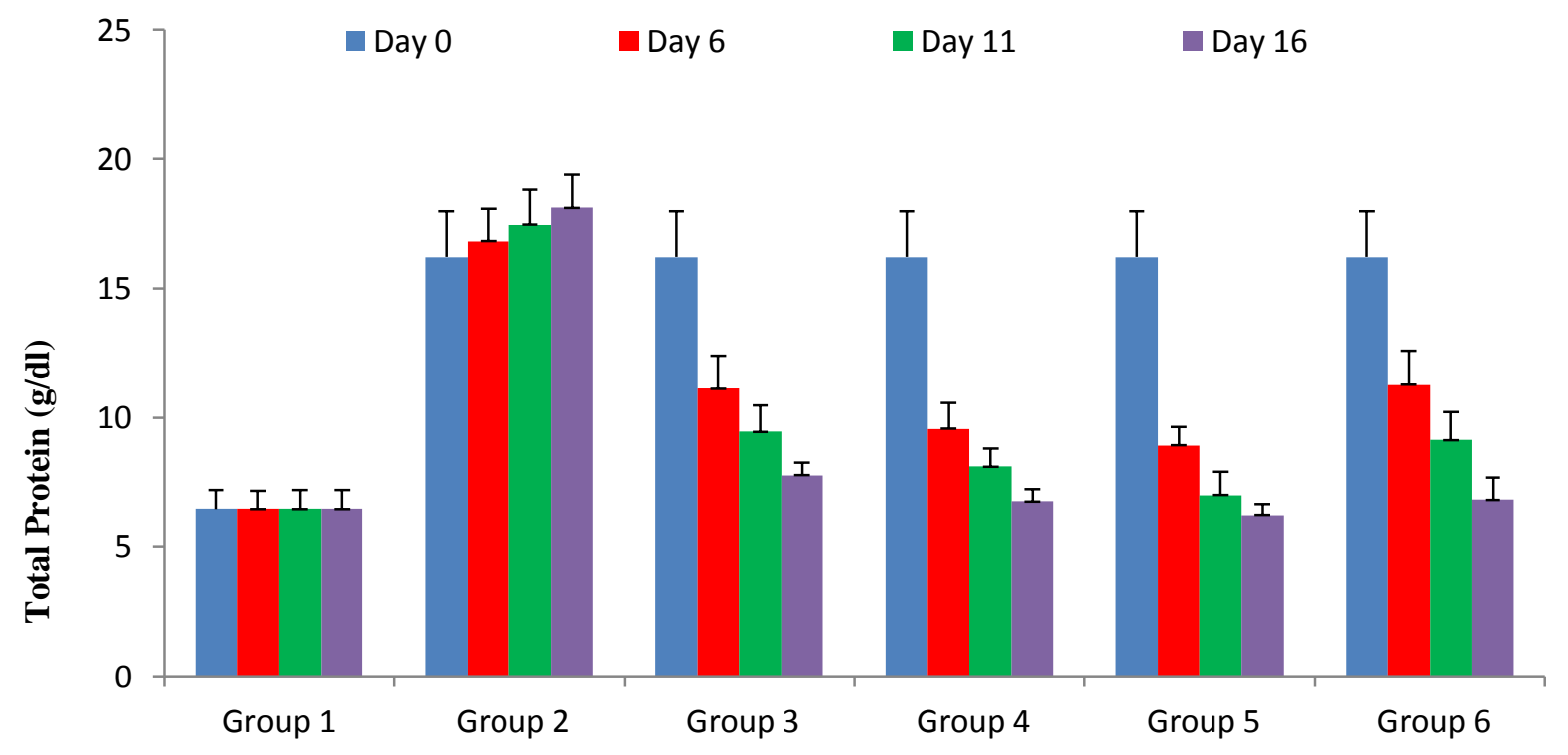

Figure 7: Total Proteins (TP) level of Albino Rats exposed to Salmonella typhi bacteria before treatment with Milletia aboensis 


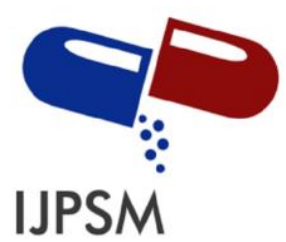

Isirima, Joshua Charles et al, Int. Journal of Pharmaceutical Sciences and Medicine (IJPSM), Vol.6 Issue. 1, January- 2021, pg. 8-30

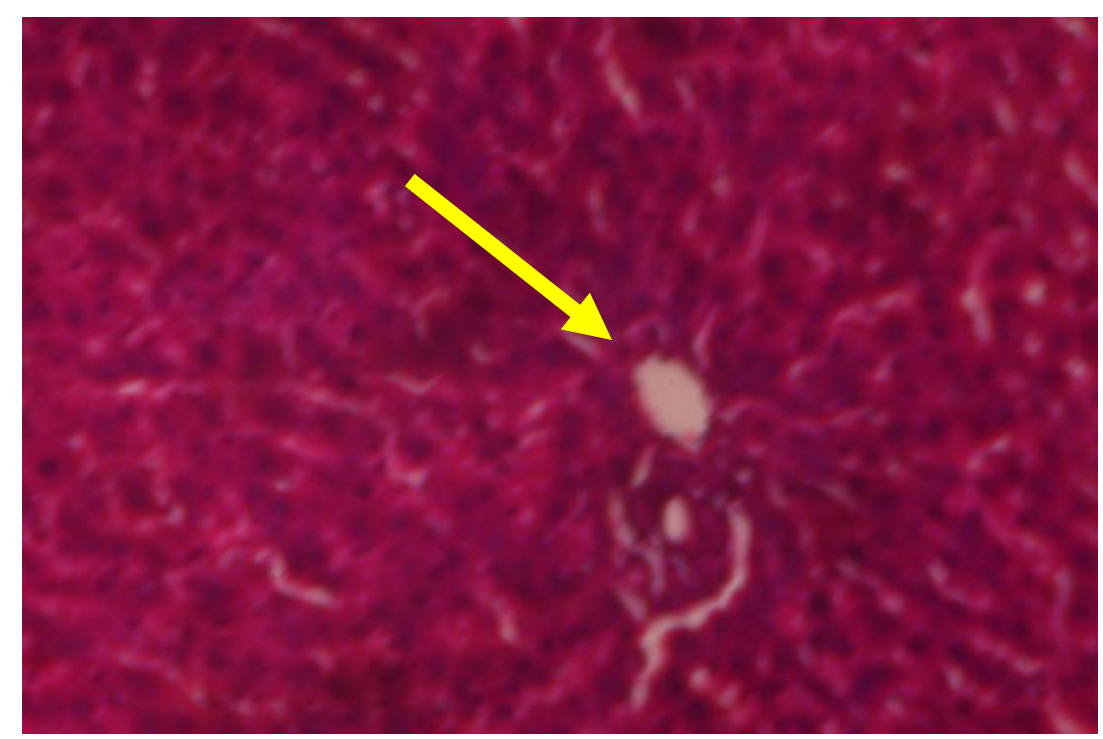

ISSN: 2519-9889

Impact Factor: 3.426

Plate 1: Photomicrograph of liver tissues of normal rats (group one) after 5 days of study, showing normal architecture with prominent central vein as indicated with the arrow

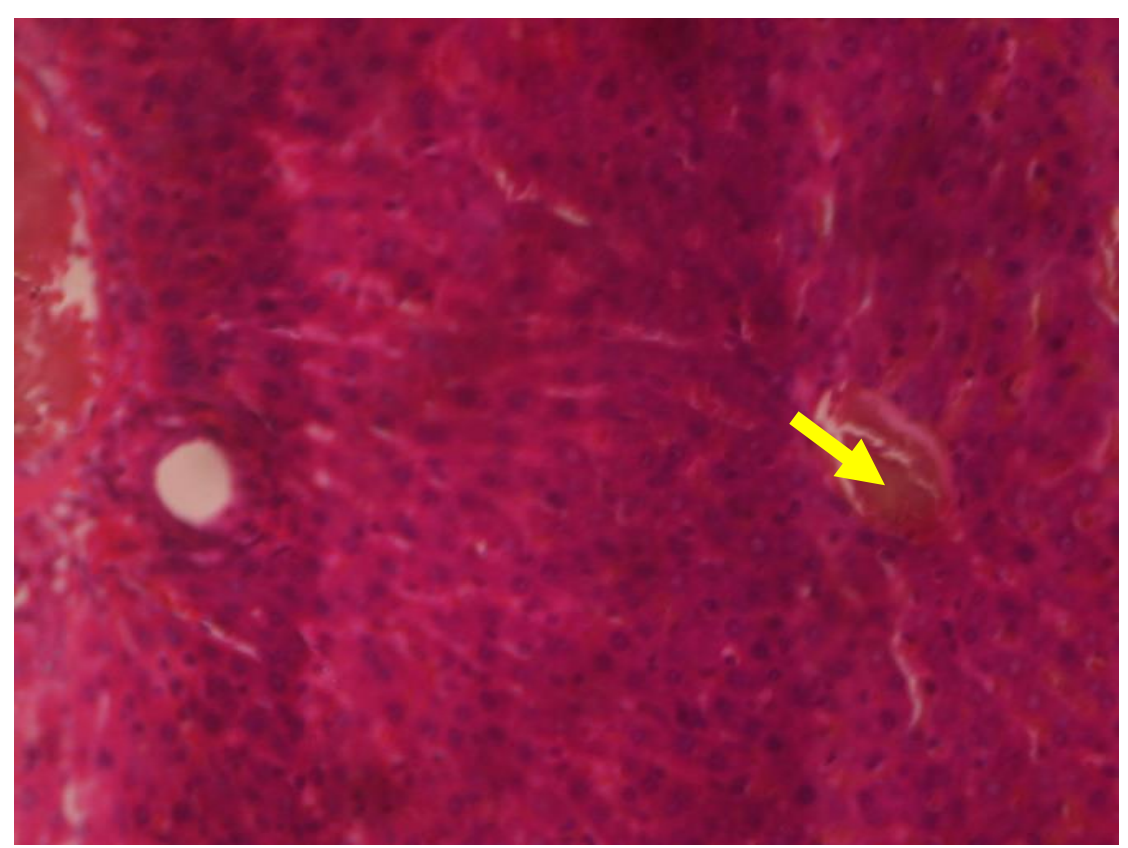

Plate 2: Photomicrograph of liver tissues of rats infected with S. typhi, without treatment (group two) for 5 days showing liver necrosis with poorly defined architecture as shown by the arrow. 


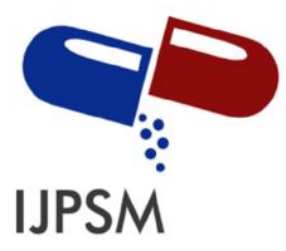

Isirima, Joshua Charles et al, Int. Journal of Pharmaceutical Sciences and Medicine (IJPSM),

Vol.6 Issue. 1, January- 2021, pg. 8-30

ISSN: 2519-9889

Impact Factor: 3.426

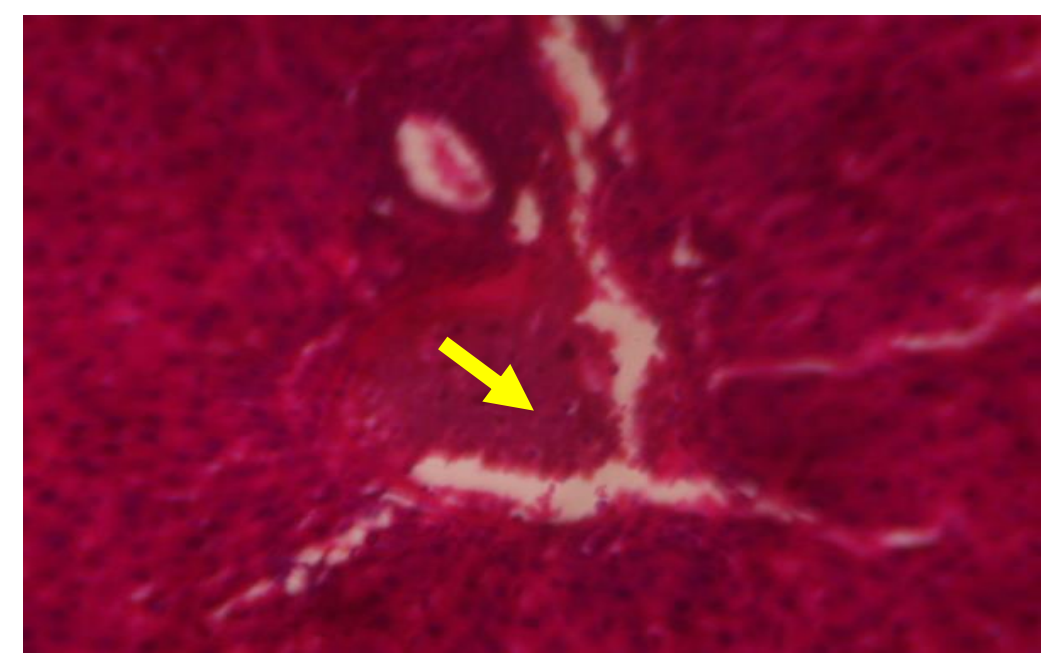

Impact Factor: 3.426

Plate 3: Photomicrograph of liver tissues of rats infected with $S$. typhi and treated with $100 \mathrm{mg} / \mathrm{kg}$ of $M$. aboensis (group three) for 5 days, showing high level of inflammatory polymophornuclear cells, with the portal triad presenting a hepatic artery and vein as indicated by the arrow

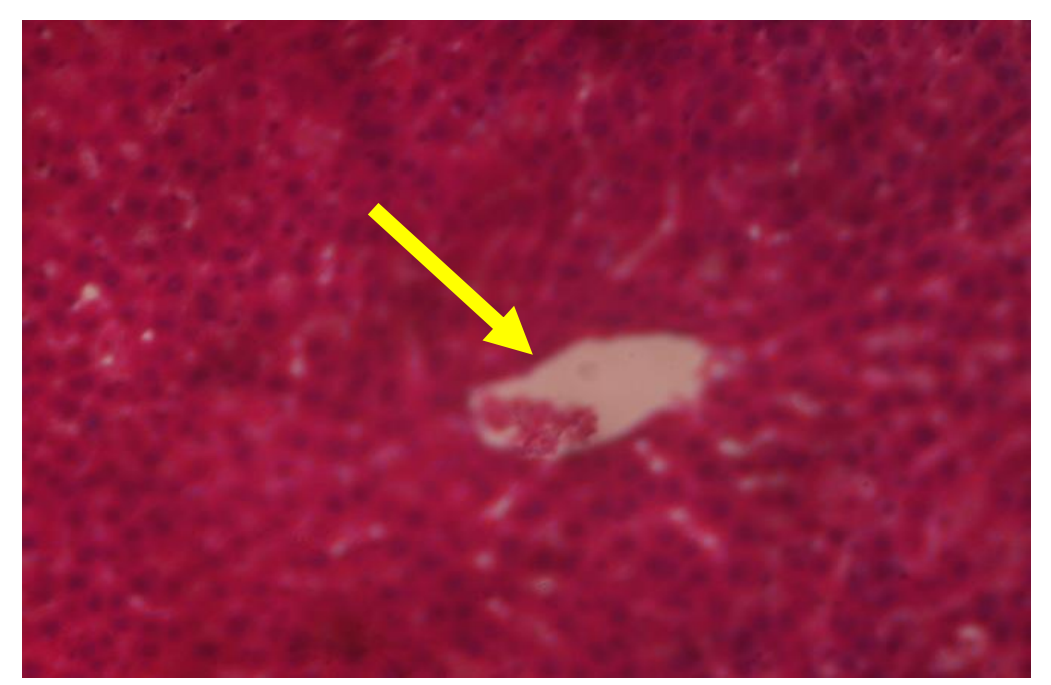

Plate 4: Photomicrograph of liver tissues of rats infected with $S$. typhi and treated with $200 \mathrm{mg} / \mathrm{kg}$ of M. aboensis (group four) for 5 days, showing liver with a prominent central vein (as indicated by the arrow), with readily placed hepatic plates and well dilated sinosoids. 


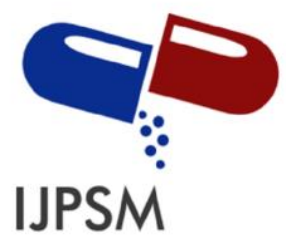

Isirima, Joshua Charles et al, Int. Journal of Pharmaceutical Sciences and Medicine (IJPSM), Vol.6 Issue. 1, January- 2021, pg. 8-30

ISSN: 2519-9889

Impact Factor: 3.426

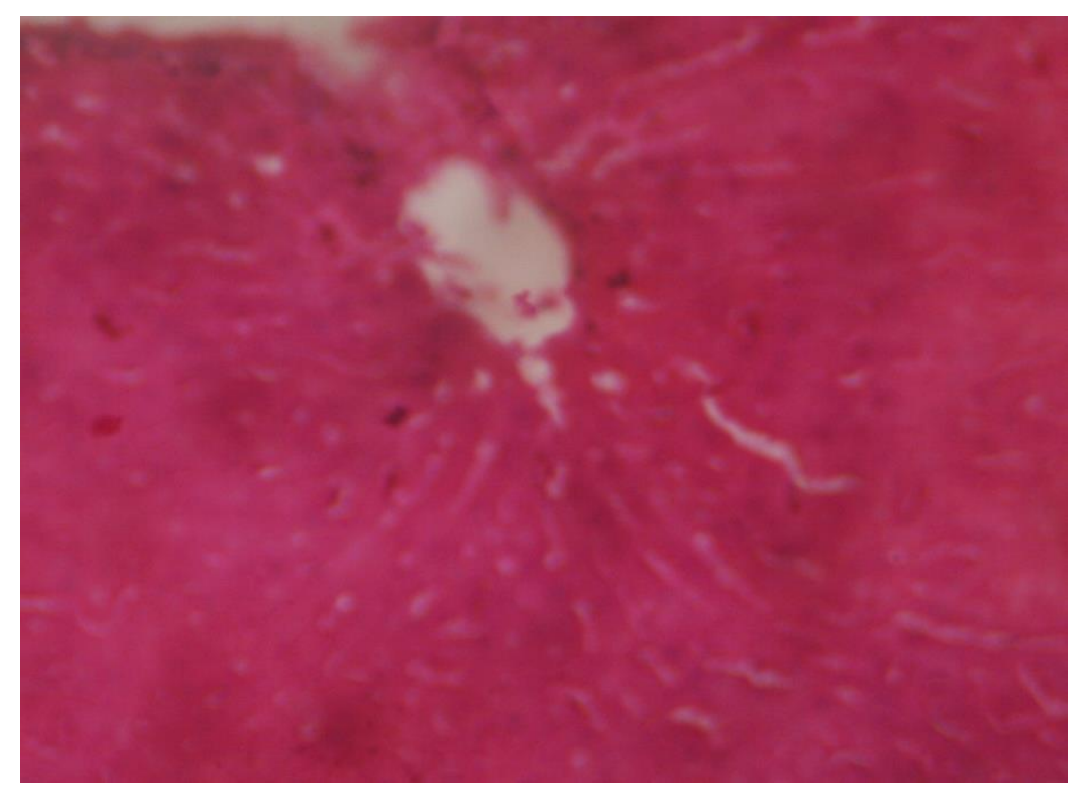

Plate 5: Photomicrograph of liver tissues of rats infected with $S$. typhi and treated with $400 \mathrm{mg} / \mathrm{kg}$ of M. aboensis (group four) for 5 days, showing liver with central veins from the liver lobules in proper position indicating normal architectural appearance.

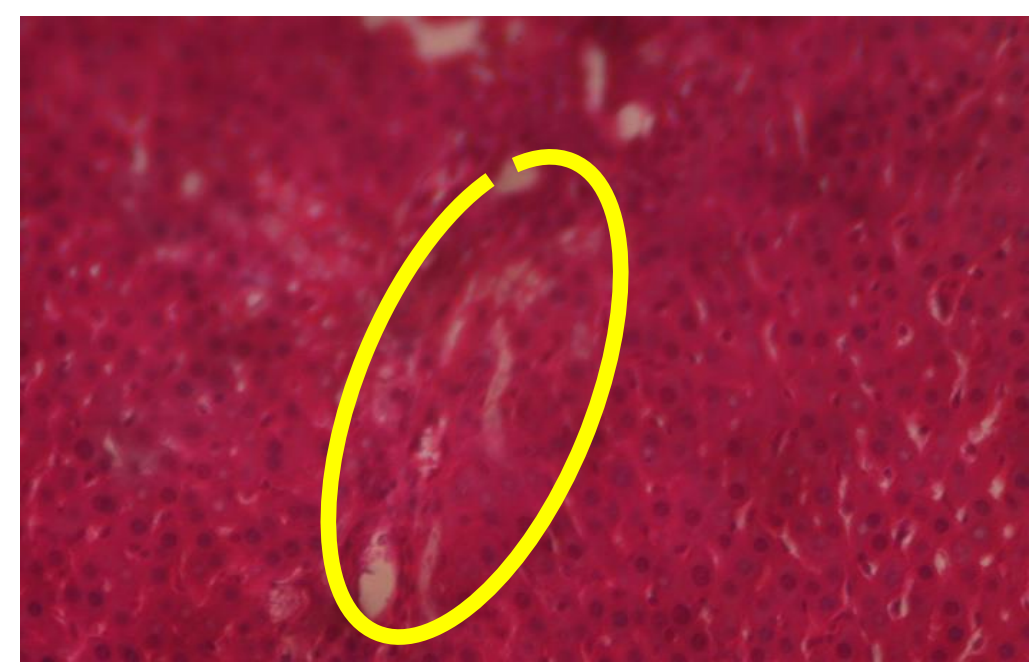

Plate 6: photomicrograph of liver tissues of $S$. typhi infected rats treated with $7.14 \mathrm{mg} / \mathrm{kg}$ of Ciprofloxacin (group six) for 5 days, showing well dilated sinusoids with no inflammatory cells with intense portal triad branching of the hepatic artery and vein as indicated with the circular shape 


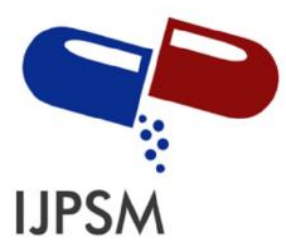

Isirima, Joshua Charles et al, Int. Journal of Pharmaceutical Sciences and Medicine (IJPSM), Vol.6 Issue. 1, January- 2021, pg. 8-30

ISSN: 2519-9889

Impact Factor: 3.426

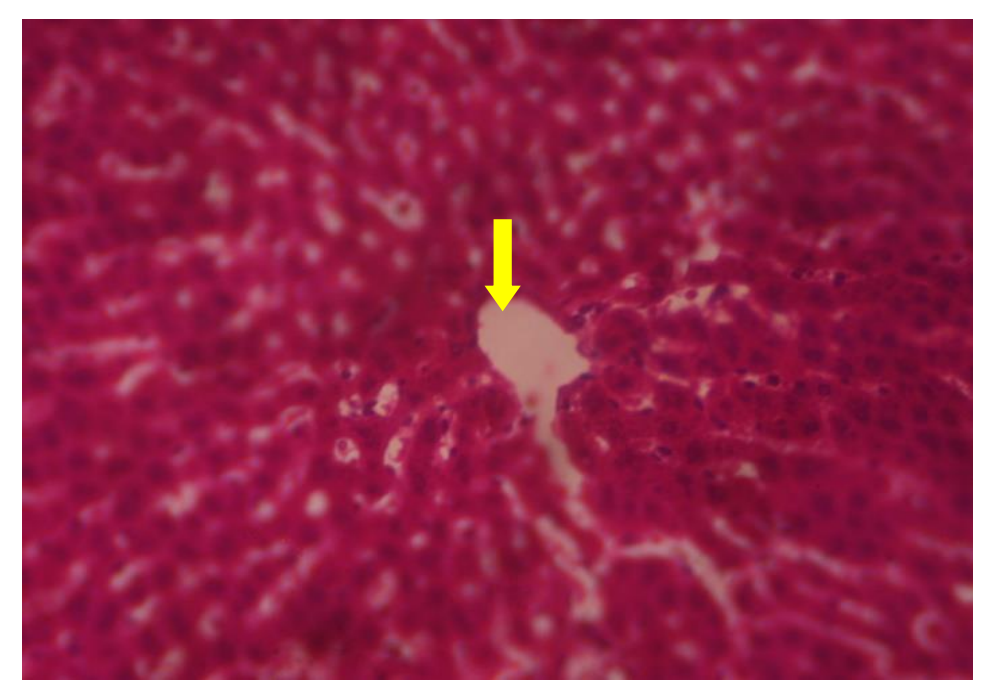

Plate 7: Photomicrograph of liver tissues of normal rats (group one) after 10 days of study, showing normal architecture with radially placed central vein and hepatic plates

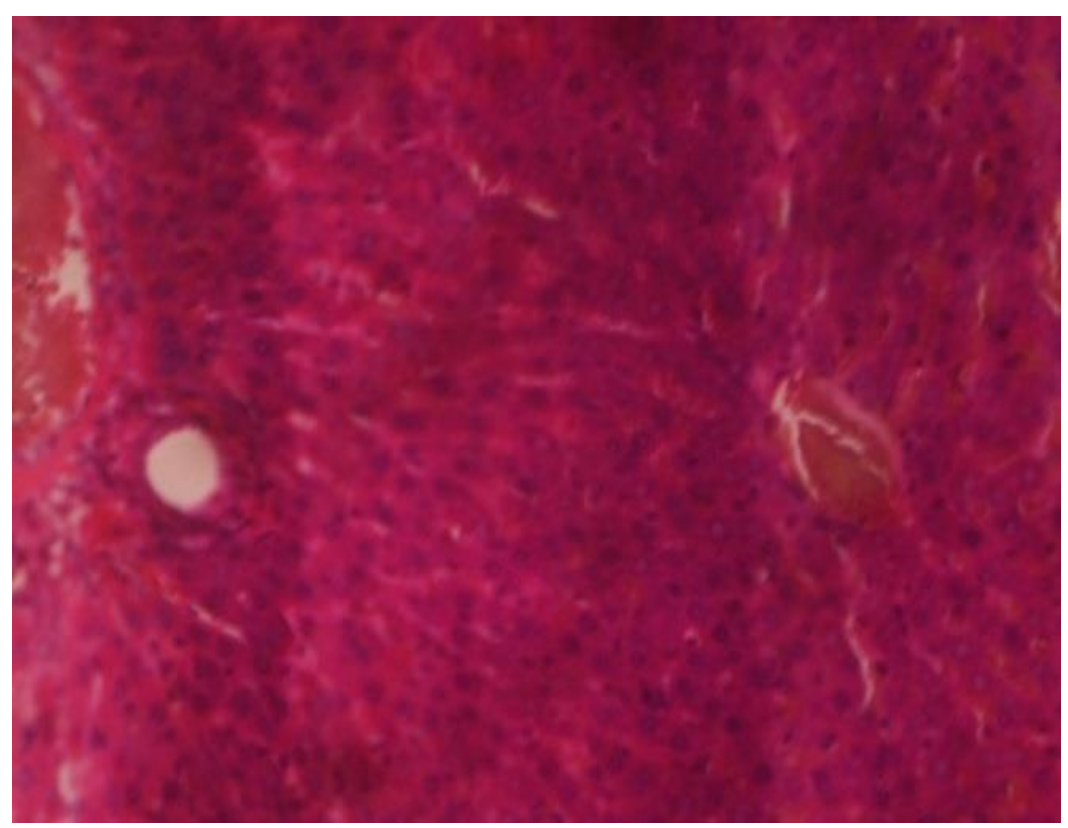

Plate 8: Photomicrograph of liver tissues of rats infected with S. typhi, without treatment (group two) for 10 days showing liver partly necrotized with poorly defined architecture as shown by the arrow. 


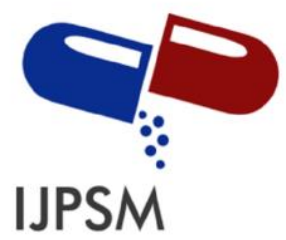

Isirima, Joshua Charles et al, Int. Journal of Pharmaceutical Sciences and Medicine (IJPSM),

Vol.6 Issue. 1, January- 2021, pg. 8-30

ISSN: 2519-9889

Impact Factor: 3.426

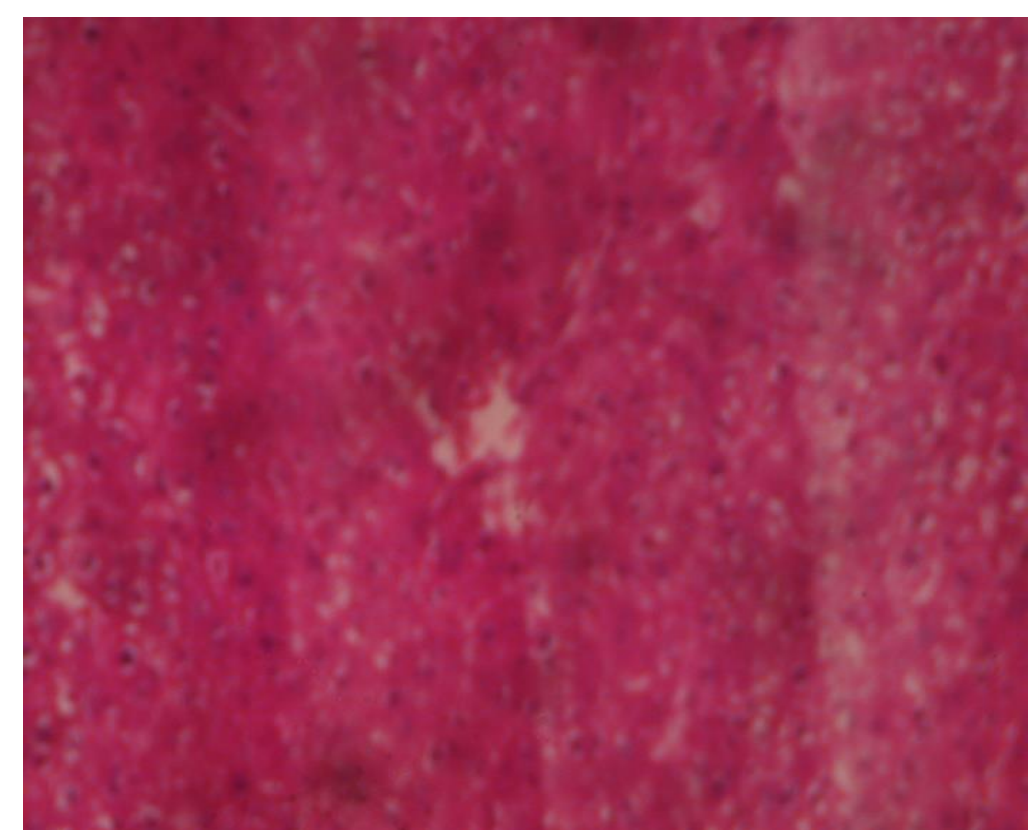

Plate 9: Photomicrograph of liver tissues of rats infected with $S$. typhi and treated with $100 \mathrm{mg} / \mathrm{kg}$ of $M$. aboensis (group three) for 10 days, showing poorly differentiated liver cells although with well dilated sinusoids and the presence of inflammatory cells.

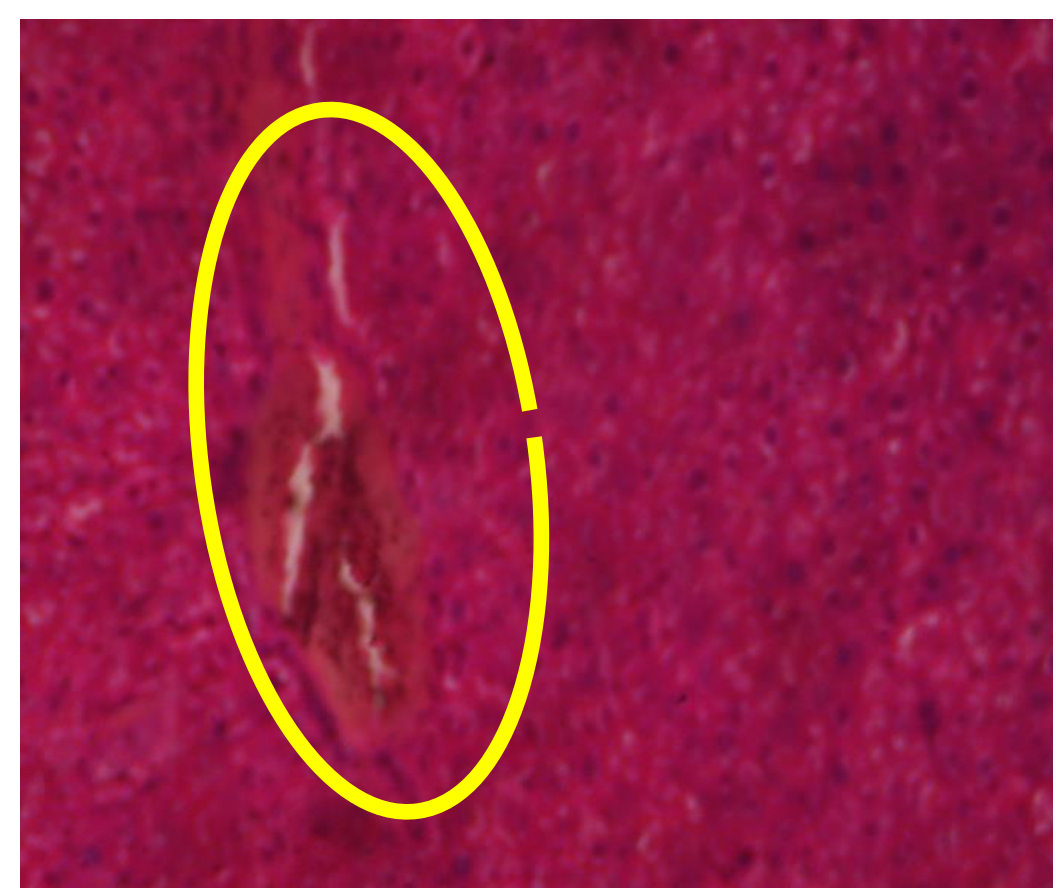

Plate 10 : Photomicrograph of liver tissues of rats infected with $S$. typhi and treated with $200 \mathrm{mg} / \mathrm{kg}$ of M. aboensis (group four) for $\mathbf{1 0}$ days, showing liver lobule containing hepatic plates that are radially placed with dilated sinusoids and marked interlobar region containing branches of hepatic arteries and portal vein without inflammatory cells (see circular figure).. 


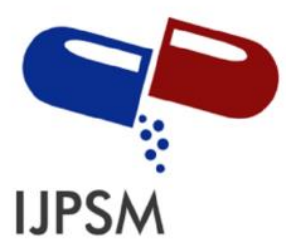

Isirima, Joshua Charles et al, Int. Journal of Pharmaceutical Sciences and Medicine (IJPSM), Vol.6 Issue. 1, January- 2021, pg. 8-30

ISSN: 2519-9889

Impact Factor: 3.426

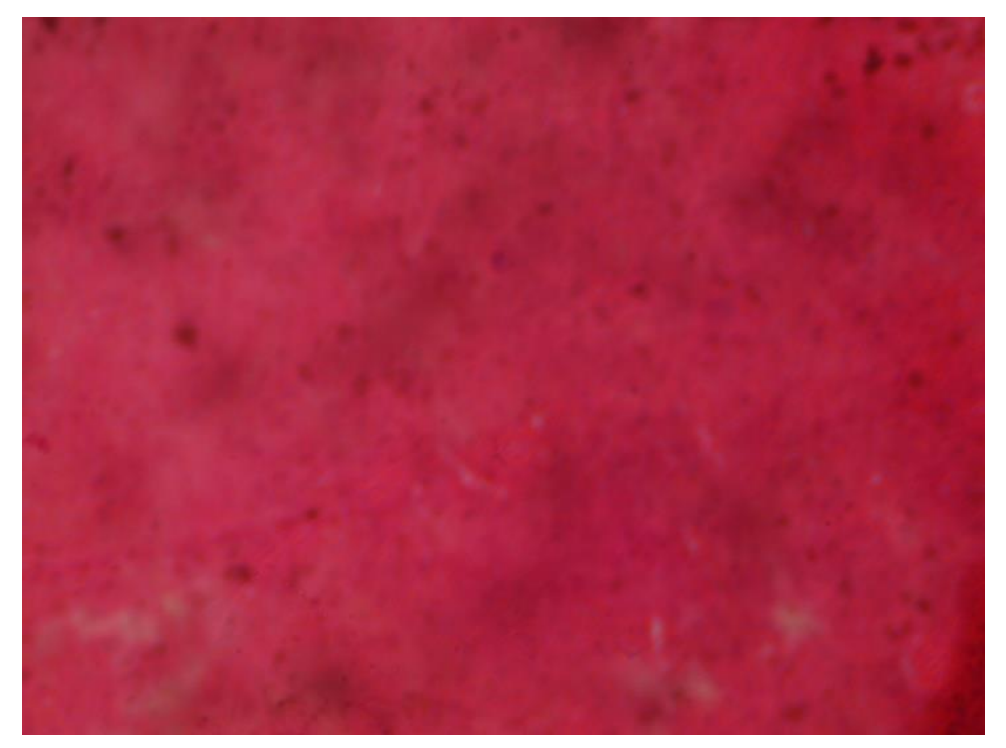

Plate 11: Photomicrograph of liver tissues of rats infected with $S$. typhi and treated with $400 \mathrm{mg} / \mathrm{kg}$ of M. aboensis (group five) for 10 days, showing normal hepatocytes and central vein.

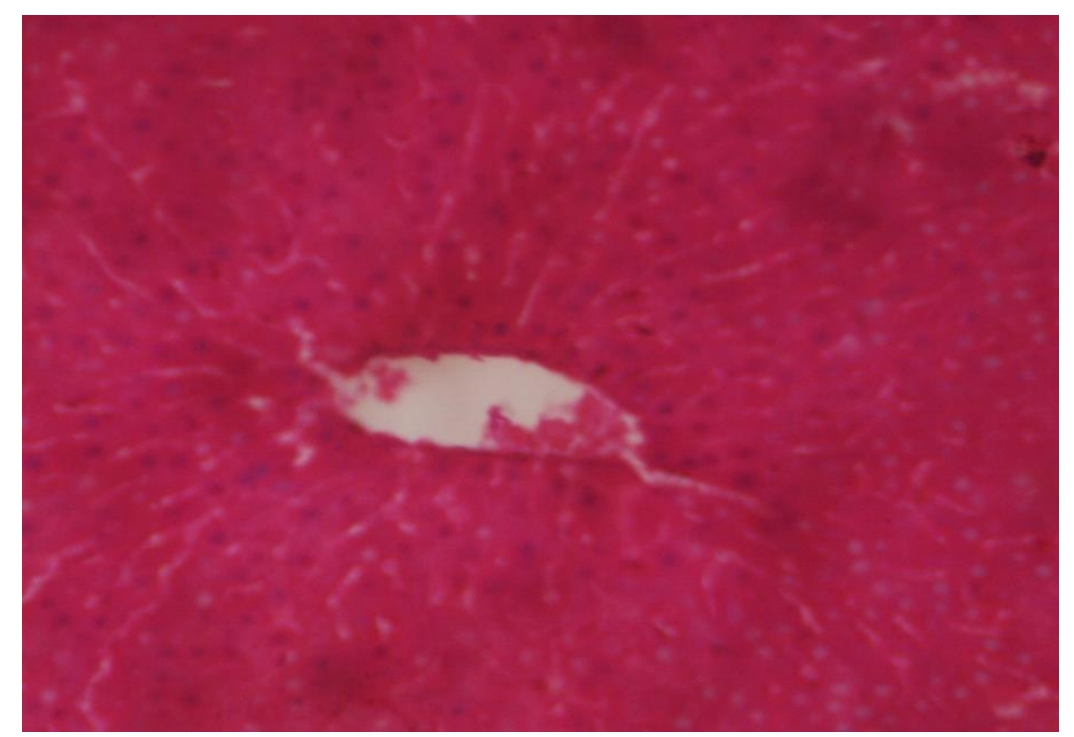

Plate 12: photomicrograph of liver tissues of $S$. typhi infected rats treated with $7.14 \mathrm{mg} / \mathrm{kg}$ of Ciprofloxacin (group six) for 10 days, showing well defined hepatic plates with no presence of inflammatory cells. 


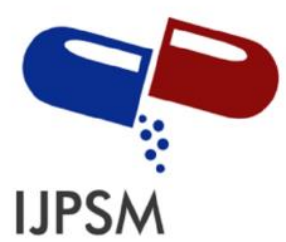

Isirima, Joshua Charles et al, Int. Journal of Pharmaceutical Sciences and Medicine (IJPSM), Vol.6 Issue. 1, January- 2021, pg. 8-30

ISSN: 2519-9889

Impact Factor: 3.426

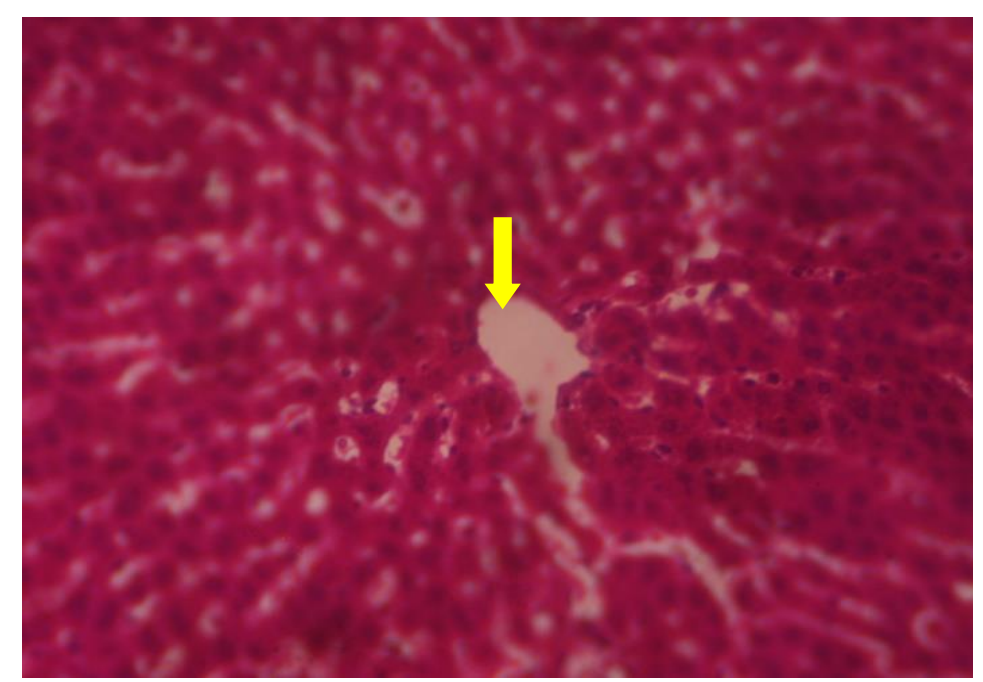

Plate 13: Photomicrograph of liver tissues of normal rats (group one) after 15 days of study, showing normal architecture with radially placed central vein and hepatic plates

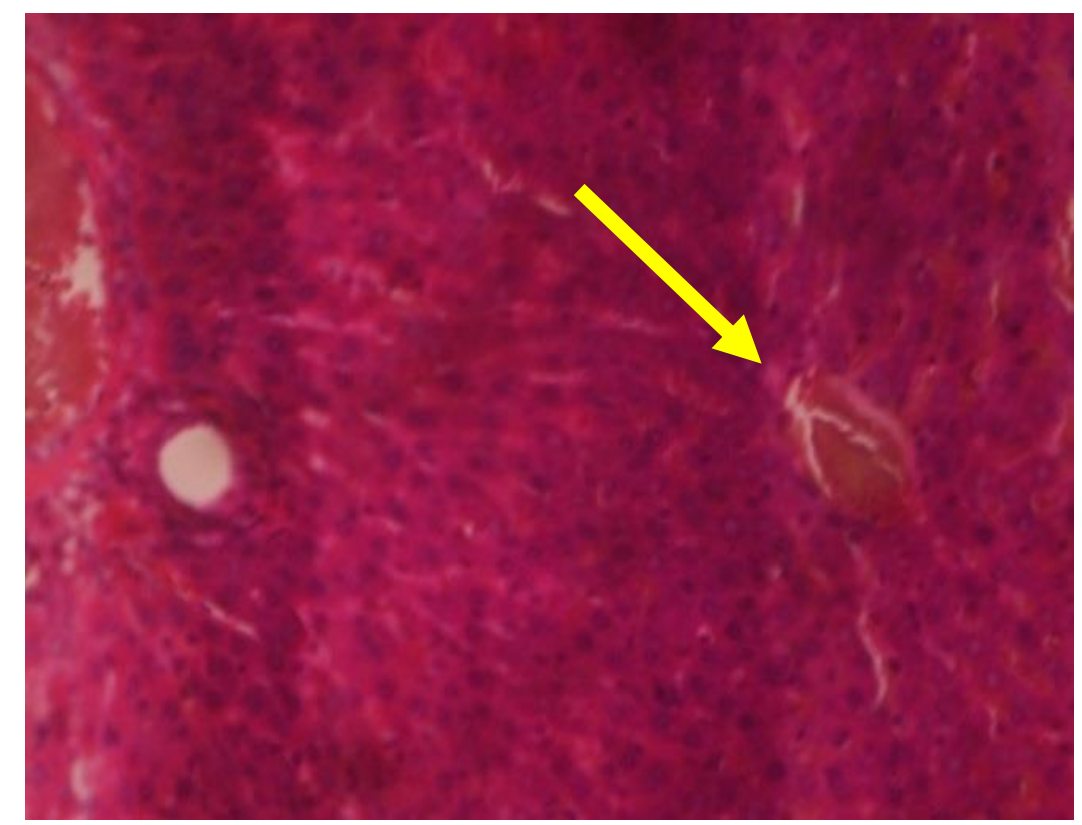

Plate 14: Photomicrograph of liver tissues of rats infected with S. typhi, without treatment (group two) for 15 days showing liver partly necrotized with poorly defined architecture as shown by the arrow. 


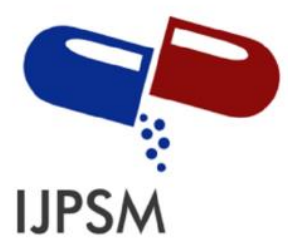

Isirima, Joshua Charles et al, Int. Journal of Pharmaceutical Sciences and Medicine (IJPSM), Vol.6 Issue. 1, January- 2021, pg. 8-30

ISSN: 2519-9889

Impact Factor: 3.426

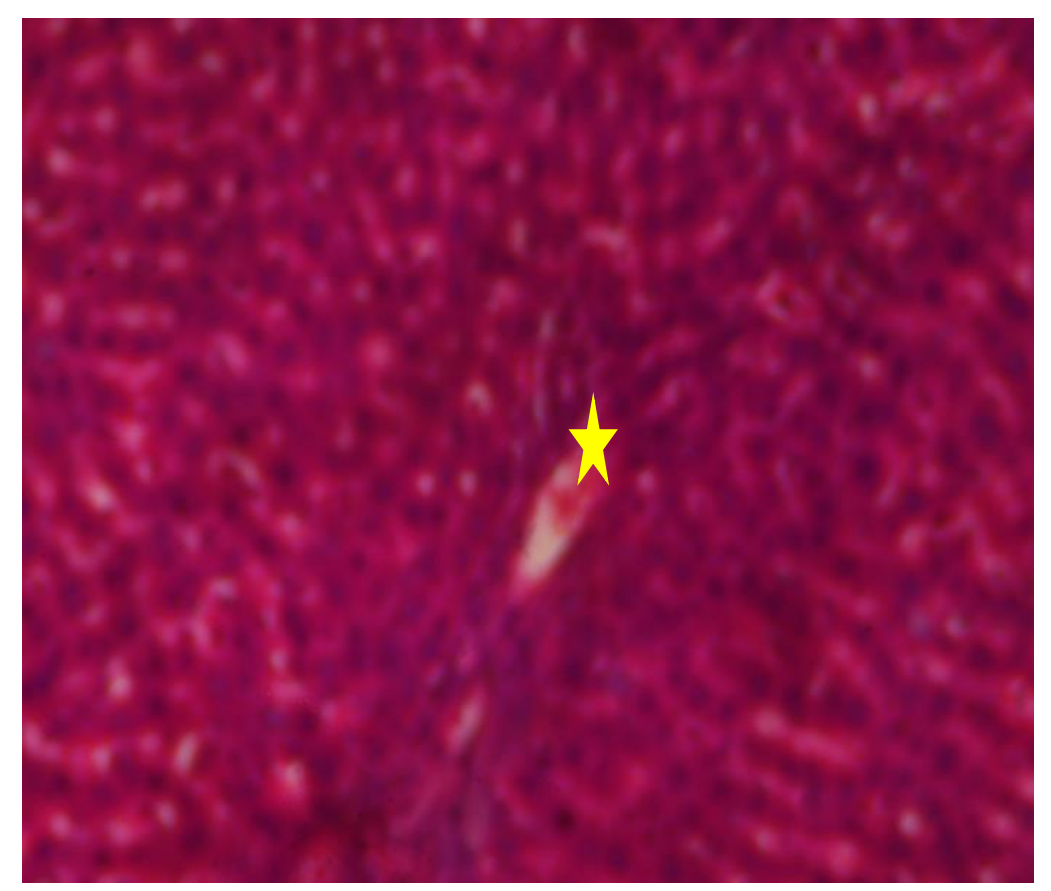

Plate 15: Photomicrograph of liver tissues of rats infected with $S$. typhi and treated with $100 \mathrm{mg} / \mathrm{kg}$ of M. aboensis (group three) for 15 days, showing interlobe junction of the hepatic tissue with the presence of portal veins and arteries (as indicated by the star shape 


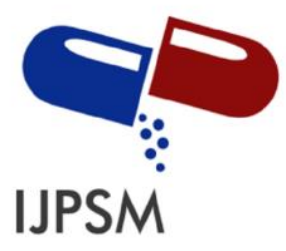

Isirima, Joshua Charles et al, Int. Journal of Pharmaceutical Sciences and Medicine (IJPSM), Vol.6 Issue. 1, January- 2021, pg. 8-30

ISSN: 2519-9889

Impact Factor: 3.426

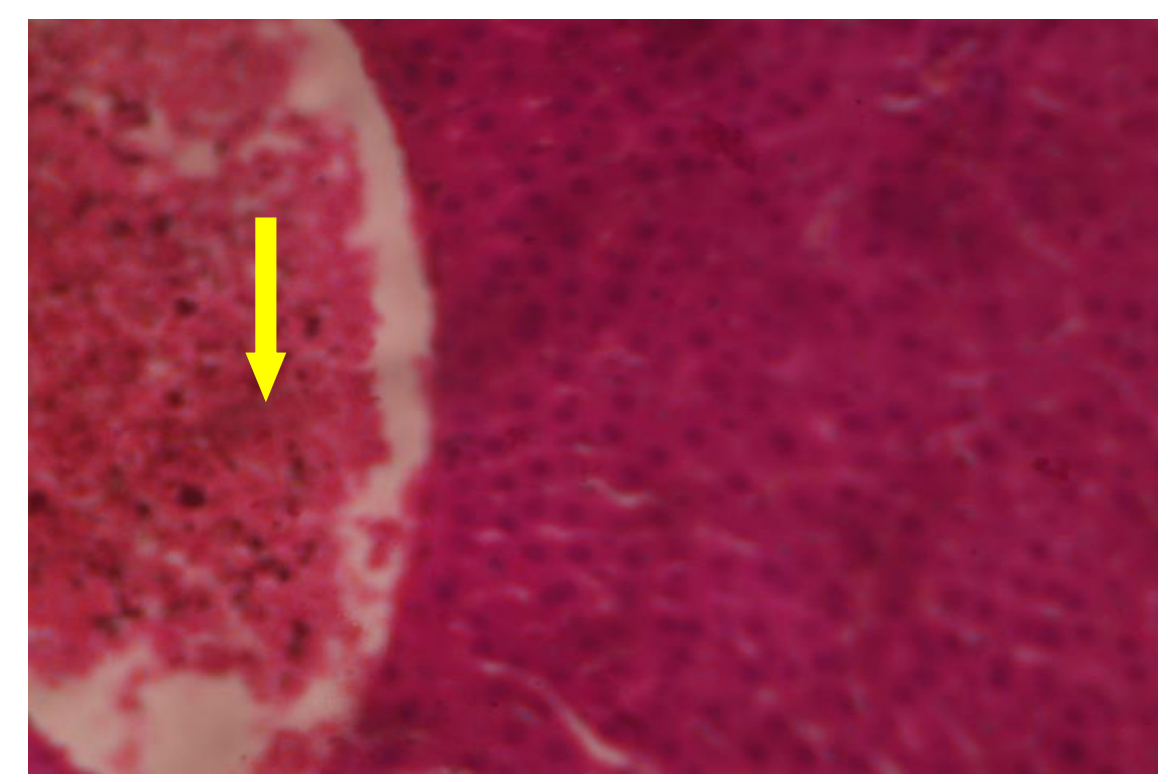

Plate 16: Photomicrograph of liver tissues of rats infected with $S$. typhi and treated with $200 \mathrm{mg} / \mathrm{kg}$ of M. aboensis (group four) for 15 days, showing intact architecture with central vein containing blood cells marked by the arrow

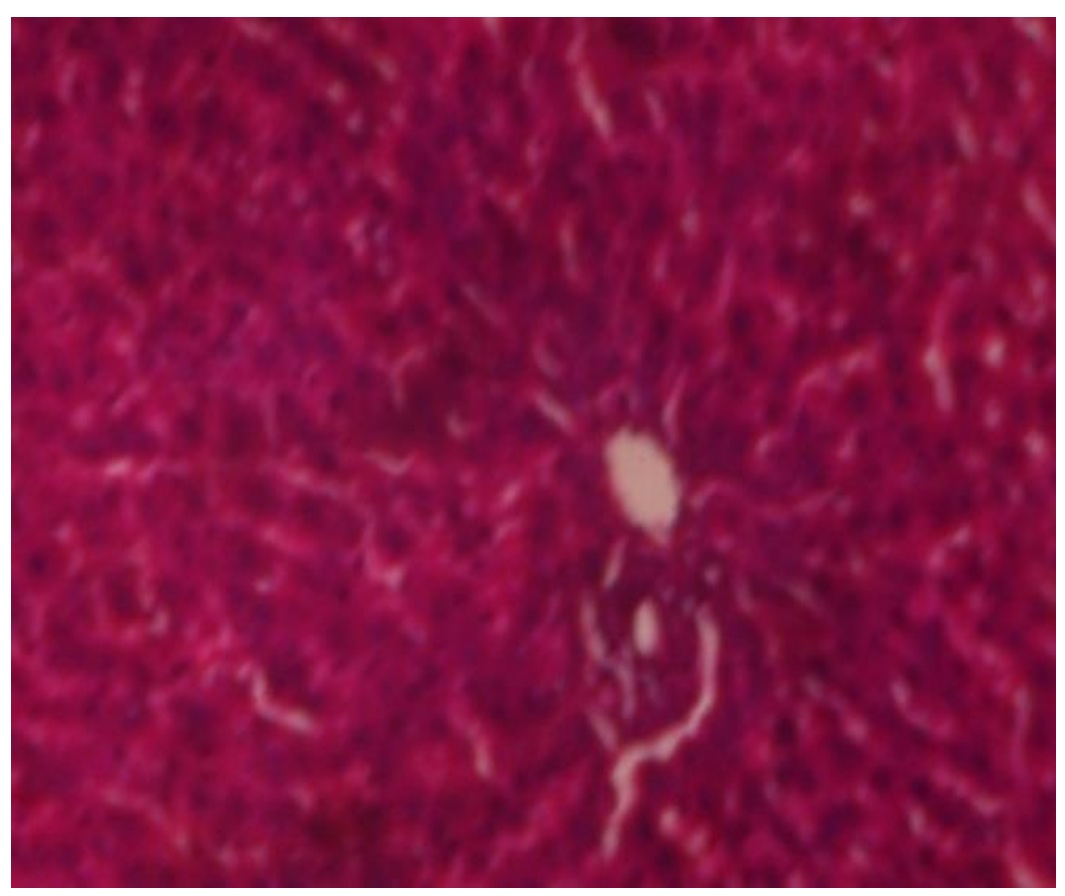

Plate 17: Photomicrograph of liver tissues of rats infected with $S$. typhi and treated with $400 \mathrm{mg} / \mathrm{kg}$ of $M$. aboensis (group four) for 15 days, showing intact and normal architecture. 


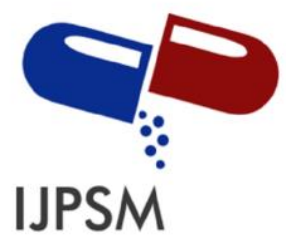

Isirima, Joshua Charles et al, Int. Journal of Pharmaceutical Sciences and Medicine (IJPSM), Vol.6 Issue. 1, January- 2021, pg. 8-30

ISSN: 2519-9889

Impact Factor: 3.426

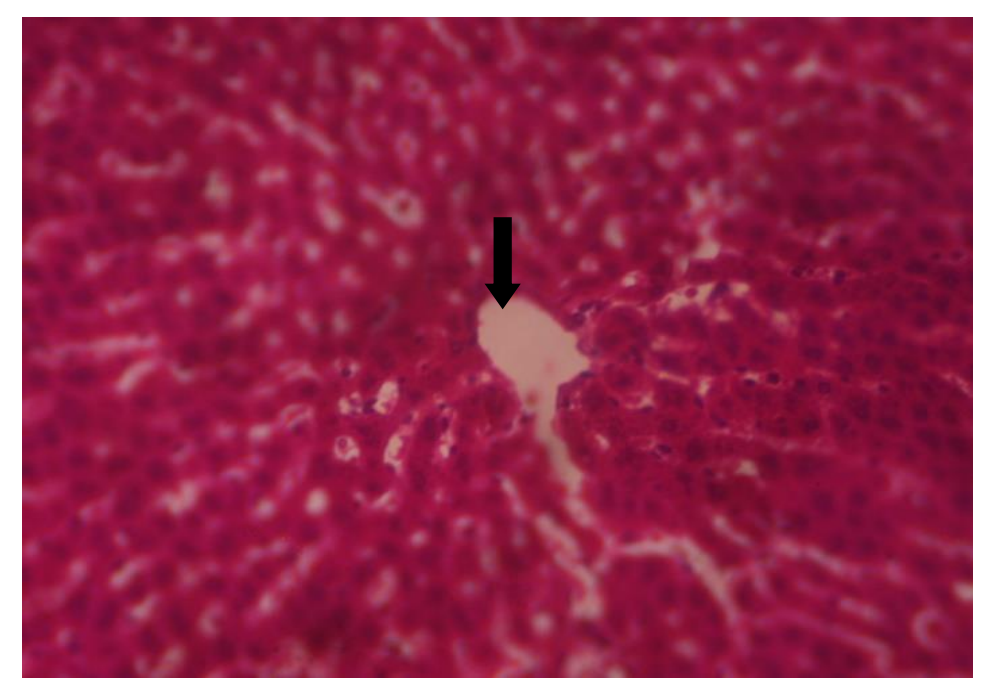

Plate 18: photomicrograph of liver tissues of $S$. typhi infected rats treated with $7.14 \mathrm{mg} / \mathrm{kg}$ of Ciprofloxacin (group six) for 15 days, showing well radially placed central vein and hepatic plates and well dilated sinusoids and some Kupfer cells were seen in the sinusoidal place.

\section{Discussion}

In this study it was observed that inoculation of Wistar rats with Salmonella typhi caused an increase in the levels of aspartate aminotransferase (AST), alanine aminotransferase (ALT), alkaline phosphatase (ALP), total bilirubin (TB), albumin and total protein (TP) and an insignificant increase in Conjugate Billirubin (CB). These findings are in line with the reports of Adeyi et al., (2013) and Damilola et al., (2015) and Isirima et al., (2018). These changes as remarked by Sallie et al., (1991) may have occurred due to hepatic damage resulting from local or systemic adverse effects of particular endotoxin, non-specific inflammatory reactions in response to intestinal perforations and cytotoxins generated and released by Salmonella typhi that have infected Kuffer cells. It was also observed that administration of ethanol root extract of Milletia aboensis reversed the adverse hepatotoxicological changes and this observation also agrees with the findings of Attama et al., (2014), who also reported a reduction in liver and kidney markers including aspartate aminotransferase (AST) and alanine aminotransferase (ALT), alkaline phosphatise (ALP), serum total and conjugated Bilirubins on administration of Milletia aboensis root extract extract to Wistar rats. These reversal effects could be hepatoprotective in nature. These effects could be attributed to anti-bacterial potentials of Milletia aboensis by eliminating the bacteria from the Kuffer cells. Infection of Wistar rats resulted in severe hepatic necrosis, which agrees with the reports of Haque, et al., (2011) and Isirima et al., (2018). Such liver pathology has been attributed to liver disease (Mohd et al., 2013) and hepatic damage resulting from local or systemic adverse effects of particular endotoxin, non-specific inflammatory reactions in response to intestinal perforations and cytotoxins generated and released by Salmonella typhi that have infected Kuffer cells (Sallie et al., 1991). Treatment of infected animals with the different doses of the extract reversed the necrotic tissues gradually back to normal histo-architecture on day 16 especially with the high dose, indicating that the extract was effective at reversing these pathological changes in the liver. These effects could also be attributed to anti-bacterial activity of the extract against Salmonella typhi, which is in line with the report of Blessing and Uzoma (2014), who found Millettia aboensis to have exhibited significant antibacterial activity against clinical Isolates of S. aureus, P. aeruginosa and K. Pneumonia. This implies that, it is the elimination of the organism in the liver, that enabled the body to gradually metabolized and reduce the endotoxins and cytotoxins produced by the organism. 


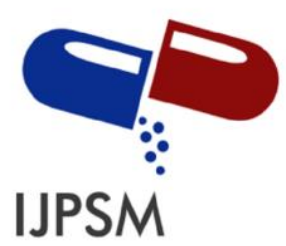

Isirima, Joshua Charles et al, Int. Journal of Pharmaceutical Sciences and Medicine (IJPSM), Vol.6 Issue. 1, January- 2021, pg. 8-30

ISSN: 2519-9889

Impact Factor: 3.426

\section{Conclusion}

Ethanol root extract of Millettia aboensis reversed the hepatological changes caused by S. typhi infection in Wistar rats in our study.

\section{References}

[1]. Abro, A. H., Abdou, A. M., Gangwani, A. M. U. (2009). Clinical and laboratory profile of enteric fever in children in northern India Younis NJ, Hussaini HS, Pak J Med Sci, 25(2), 166-171

[2]. Adeyi, A. O., Jinadu, A. M., Arojojoye, O. A., Alao, O. O., Ighodaro, O. M., \& Adeyi, O. E. (2013). In vivo and in vitro antibacterial activities of Momordica charantia on Salmonella typhi and its effect on liver function in typhoid-infected rats. Journal of Pharmacognosy and Phytotherapy, 5(11), 183-188.

[3]. Adonu, C. C., Ugwueze, M. E., Ozioko, C. A. (2013). Phytochemical analyses of ethanol and water extracts of Millettia aboensis, Cuscuta reflexa, Daniella oliveri and Synclisia scabrida. Int J Pharm Biol Sci, 3(2): 64-69.

[4]. Ackers, M. L., Puhr, N. D., Tauxe, R. V., Mintz, E. D. (2000). Laboratory-Based Surveillance of Salmonella Serotype Typhi infections in the United States. Antimicrobial resistance on the Rise. JAMA 283: 2668-2673.

[5]. Attama, A. A., Ofokansi K, C., Kenechukwu, F. C., Ugwueze, M. E. (2014). Evaluation of the Hepatoprotective Effect of Aqueous and Ethanolic Root Extracts of Millettia Aboensis on Acetaminophen-Induced Hepatotoxicity in Experimental Rats. Indian Journal of Novel Drug Delivery, 2014, 256-264.

[6]. Babson, L. A., Greeley, S. J., Coleman, C. M., \& Philips, G. D. (1966). Clin. Chem., 12, 482-490.

[7]. Baker, J. R. (1945). Cytological Technique. (2nd ed.), (p. 211). London: Methuen.

[8]. Blessing, O. O., Uzoma, A. O. (2014). Antimicrobial Properties of Ethanol Leaf Extract of Millettia aboensis on Some Selected Clinical Isolates, Universal Journal of Plant Science 2(5): 97-101.

[9]. Crump, J. A., Luby, S. P,, Mintz, E.D. (2004). The global burden of typhoid fever. Bull World Health Organ 82:346-353.

[10].Damilola, A. O., Garba, J. D., Wilson, I. E. \& Ume, U. A. (2015). Anti-typhoid and hepatic response in Salmonella typhi infected rats treatedwith ethanol leaf extract of Tithonia diversifolia. Asian Journal of Plant Science and Research. 5(8), 34-46.

[11].Doumas, B. T., Watson, W. A., \& Biggs, H. G., (1971). Clin. Chim. Acta, 31, 87.

[12].Grant, G. H. (1987). Amino Acids and Proteins; Fundamentals of Clinical Chemistry, Tietz, N. W. Editor, $3^{\text {rd }}$ Edition. WB Saunders Company Philadelphia USA, 328-329.

[13].Gupta, M. P., Solis, P. N., Calderon, A. I., Guionneau, S. F., Correa, C., galdames, C., Guerra, C., Espinosa, A., Alvenda, G. I., Robles, G., Ocampo, R.,. (2005). Medical ethnobotany of the teribes of Bocas del Toro. Panama. J Ethanopharmacol, 96, 389-401.

[14].Hanan, B., Akram, H., Hassan, R., Ali, H., Zeinab, S., \& Bassam, B. (2013). Techniques for the Extraction of Bioactive Compounds from Lebanese Urtica dioica. Maceration method. American Journal of Phytomedicine and Clinical Therapeutics, 1(6), 507-513

[15].Haque, S. S., Sharan, A., \& Kumar U. (2011). Histopathological examination of formulated drugs against typhoid. Research In Pharmaceutical Biotechnology, 3(10), 135-141.

[16].Iroha, I, R., Ilang, D. C., Ayogu, T. E, Oji, A. E., Ugbo, E. C. (2010). Screening for anti-typhoid activity of some medicinal plants used in traditional medicine in Ebonyi state, Nigeria. Journal of Pharmacy and Pharmacology, 2010, 4(12), 860-864.

[17].Isirima Joshua Charles and Siminialayi Iyeopu Minakiri (2018). Effect of Chromolaena Odorata on Hepatotoxicology and Histopathology in the Liver Induced by Salmonella Typhi in Wistar Rats Isirima Joshua European Scientific Journal Vol.14, 1-16.

[18].Ivanoff, B. (1995). Typhoid fever: global situation and WHO recom-mendations. Southeast Asian J. Trop. Med. Public Health 26(Suppl 2):1-6.

[19].Klein, B., Read, P. A. \& Babson, L. A. (1960). Clin. Chem., 6, 269-275. 


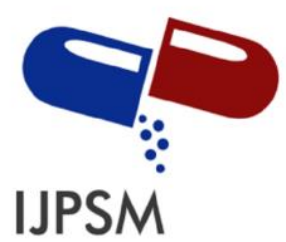

Isirima, Joshua Charles et al, Int. Journal of Pharmaceutical Sciences and Medicine (IJPSM), Vol.6 Issue. 1, January- 2021, pg. 8-30

ISSN: 2519-9889

Impact Factor: 3.426

[20].Mead, R. and Curnow, R. N. (1982). A simple statistical method in Agriculture and experimental Biology. Charpman Hall, London, UK, pp: 33-46.

[21].Mirsadraee, M., Shirdel, A., \& Roknee, F. (2007). Typhoid Myopathy or typhoid hepatitis: A matter of debate. Indian Journal of Medical Microbiology ; 25:351-3.

[22].Mohd Azam Hyder, Marghoob Hassan and abdelmarouf Hassan Mohieldein (2013). Comparative Level of ALT, AST, ALP and GGT in liver associated disease. European Journal of Experimental Biology, 3(2), 280-284.

[23].Morgenstern, R., \& Hayes, P. C. (1991). The liver in typhoid: Always affected, not just a complication. American Journal of Gastroenterology, 86, 12335-12339.

[24]. Ozen H., G. Seçmeer, G. Kanra, Z. Ecevit, M. Ceyhan, A. Dursun, Y. Anlar (1995). Typhoid Fever with Very High Transaminase Levels, Turk J Pediatr, 37(2), 169-171.

[25].Reitman, S., \& Frankel, S. (1957). A colorimetric method for the determination of serum glutamic oxalacetic and glutamic pyruvic transaminases. Amer. J. Clin. Patho, 28, 56-63.

[26].Sallie, R., Tredger, R. S., Williams, R. (1991). Drugs and the Liver. Biopharmaceutical Drug Dispos, $12,251.259$

[27].Sarkiyayi, S., Karago, J., \& Hassan, R. (2011). Studies on Anti-Typhoid Properties of Aqueous Methanol Leaves Extract of Albizia ferruginea (Musase). International Journal of Biochemistry Research and Review, 1(1), 24-30.

[28].Schmidt, E., \& Schmidt, F. W. (1963). Enzym. Biol. Clin, 3, 1

[29].Tietz, N. W. (1995). Clinical Guide to Laboratory Tests. ( $3^{\text {rd }}$ Edition), WB Saunders Company Philadelphia P.A pp 518-519.

[30].Stormaon, M. O., McIntyre, P. B, Morris, J., Fasher, B. (1997). Hematological and biochemical changes in typhoid fever. Pediatr Infect Dis J, 16, 713-4.

[31].Uba, B. C. (2010). "Millettia". In Flora of Parkistan Page 51. Published by Science Press (Beijing) and Missouri Botanical Garden Press. Available online at efloras.org. Assessed on 10/06/2010.

[32].Wasfy, M. O., Oyofo, B. A., David, J. C. (2000). Isolation and antibiotic susceptibility of Salmonella, Shigella, and Campylobacter from acute enteric infections in Egypt.J Health Popul Nutr, 18, 33-38.

[33].Watson, K. C. (1954). Clot culture in typhoid fever. J Clin Pathol, 7, 305-307.

[34].Watson, K. C. (1978). Laboratory and clinical investigation of recovery of Salmonella typhi from blood. J Clin Microbiol 7, 122-126.

\section{A Brief Author Biography}

1. Isirima, Joshua Charles ${ }^{\mathbf{1}}$ : Isirima, Joshua Charles is a lecturer and a researcher in the Department of Biomedical Technology, in the School of Science Laboratory Technology, University of Port Harcourt, Choba, Rivers State, Nigeria. He has attained the level of Lecturer 1. He has a double M.Sc. Degrees, one in Microbiology and the other in Pharmacology and has also acquired a PhD Degree in Pharmacology, in the Department of Pharmacology, Faculty of Basic Medical Sciences, College of health Sciences, University of Port Harcourt, Choba, Rivers State, Nigeria. His areas of research interest include Ethnopharmacology, Chemotherapy, and Toxicology.

2. Angalabiri-Owei, Bekekeme Etoro' ${ }^{2}$ : Angalabiri-Owei, Bekekeme Etoro is a medical lecturer and is currently the coordinator of the Department of Pharmacology, Faculty of Basic Medical Sciences, College of health Sciences, Niger Delta University, Amassoma, Nigeria. He has attained MB BS and MSc. Degree in Pharmacology. He is currently undergoing a PhD program in Pharmacology in the University of Port Harcourt Choba, Rivers State, Nigeria. His research interest are Gastrointestinal Pharmacology, Ethnopharmacology, and Toxicology. 